\title{
Norma E CRITÉRIO DE DESEMPENHO COMO PARÂMETROS DA AVALIAÇÃo DA APRENDIZAGEM
}

\author{
MARIA do Socorro TAURINo"
}

\section{1 - APRESENTANDO o TrabalHo}

Este é um resumo, ou melhor, um extrato de Comparação entre os efeitos da avaliação por critério e norma no desempenho escolar em Matemática, tese de Doutorado com 386 páginas, concluída em dezembro de 1989 e apresentada ao Instituto de Psicologia da Universidade de São Paulo.

Trata-se portanto de um trabalho realizado na segunda metade da década passada e que teve como objetivo principal comparar tipos diferenciados de avaliação e suas influências nos resultados da aprendizagem em Matemática. Além disso, procurou também verificar a possibilidade de sistematização e aplicação de um processo completo de avaliação da aprendizagem na escola regular.

Uma vez ocorrido tão grande espaço de tempo, algumas opiniões pessoais mudaram, bem como algumas situações vivenciadas dentro do espaço escolar. A legislação também mudou dando novos enfoques, nomenclaturas e rumos à educação nacional. Entretanto, mesmo atentando a todos esses fatos, conservamos esse extrato fiel ao

- Doutora em Psicologia Escolar pela Universidtale de São Paulo. 
texto que the deu origem, esperando que o leitor possa fazer as devidas aproximações e inclusive entender a existência de algumas possíveis lacunas.

A análise estatística dos dados levantados na pesquisa mostrou que houve ganhos significantes para os diversos grupos independentemente do tipo de avaliação. Os resultados, discutidos e corroborados por uma prática de avaliação por critério experimentada no sistema SENAI-SP, fornecem sugestões de operacionalização desse processo, bem como formas de utilização das informações provenientes da análise dos desempenhos dos alunos.

\section{2 - Procurando a Fundamentaçāo Teórica}

\section{Avaliação por norma e por critério}

Basicamente há duas formas de analisar dados sobre o rendimento dos alunos. A primeira seria uma interpretação dos resultados tomando-se por base um referencial de desempenho, representado pelos objetivos de ensino e respectivos critérios de alcance. Esse tipo de interpretação descreve quais os objetivos que o aluno atingiu dentre aqueles que lhe foram propostos, sem relação a qualquer outro desempenho, seja individual ou de turma, série ou grupo.

Os testes necessários ao fornecimento de dados para esse tipo de interpretação devem ter seus itens selecionados de modo a refletir fielmente as habilidades a serem medidas. Sua construção deve estar diretamente relacionada às aprendizagens específicas trabalhadas durante o processo de ensino de forma que possam ser demonstradas pelos alunos (Gronlund, 1976).

Esse tipo de medida, "referenciada a critério", é tido como uma medida de padrão absoluto, cuja base é o desempenho individual. Em contraposição, a medida "referenciada a norma" baseia-se no desempenho do grupo, seguindo um padrão relativo. Por esta forma de análise, pode-se determinar os desempenhos, discriminando-os entre si. Na construção dos instrumentos deve-se atentar para que os itens maximizem as diferenças e promovam uma grande variabilidade de 
resultados. (Bloom et alli, 1983; Milman, 1974; Popham, 1975; Gronlund, 1976; Wang, 1977; SENAI-SP, 1985a).

\section{Avaliação por norma}

Glaser (1963, apud Himmel, 1979), foi o primeiro a distinguir provas com a finalidade de vcrificar diferenças entre os indivíduos e provas para medir mudanças, no próprio indivíduo, como efeito do processo educacional.

A mesma autora assinalando referências de Cronbach (1971) liga o enfoque normativo à ênfase dada às diferenças individuais. Isso justifica o fato de as provas tentarem uma adequação ao conceito dessas diferenças quanto a habilidades ou traços.

Partindo assim da idéia da existência de uma base naturalmente diferenciada, as provas têm como fonte de interpretação o grupo de referência ou norma. Em outras palavras, uma pontuação em determinada prova só adquire significação mediante comparação com o resultado obtido em outras, no mesmo grupo ou num grupo normativo.

Inicialmente os testes educacionais buscaram descobrir diferenças entre as pessoas de maneira a levantar possibilidade de sucesso numa situação de aprendizagem; daí sua estreita relação com os testes de inteligência e com os princípios ditados pela psicometria. Para McNeil (1981) os testes referenciados a norma, embora possam identificar pessoas de capacidades diferenciadas, são questionáveis para a avaliação do contexto curricular. Eles não revelam o que os programas realmente ensinaram nem atentam para problemas particulares que impedem a realização da aprendizagem.

Isaac e Michael (1983) concebem o teste referenciado a norma intimamente ligado à padronização a afirmam que a comparação de resultados é possível, desde que o grupo seja claramente conhecido. Os testes verificam em que medida o estudante aprendeu sem, entretanto, poder especificar o que foi realmente aprendido. A maior força dos testes referenciados a norma está em diferenciar alta e baixa performance dos estudantes. $\mathrm{O}$ teste baseado em norma destaca cada posição numa distribuição de escores, em comparação com um grupo normativo, e oferece ainda uma informação adicional a respeito de 
itens de áreas específicas de conteúdo que foram corretamente respondidos.

A avaliação baseada em norma requer procedimentos estatísticos ligados à amostragem, aos cálculos de média e desviopadrão e ao cálculo de escores padronizados. O teste, enquanto instrumento de medida, deve ter seus itens analisados a partir dos cálculos de índices de dificuldade, discriminação e fidedignidade (Vianna, 1983).

A notaçāo para os alunos pode ser feita com base no cálculo da ordem percentílica para resultados em dados numéricos ou com base nos desvios-padrão ou outros indicadores de variabilidade para resultados em dados conceituais. Outra alternativa seria utilização do próprio escore padronizado, embora, no âmbito escolar, seu uso pudesse apresentar inadequação face à tradicional utilização das escalas $0 / 10 ; 0 / 100 ;$ ou $\mathrm{A} / \mathrm{B} / \mathrm{C} / \mathrm{D} / \mathrm{E}$. Uma forma possível de sistematizar e analisar dados, considerando a avaliação por norma, encontra-se em anexo.

\section{Avaliação por critério}

McClelland (1973) diz que os instrumentos destinados à medida de resultados de aprendizagem ao invés de serem referidos a um grupo, deveriam referir-se a um critério considerando que se pretende, principalmente em sala de aula, saber se cada aluno conseguiu lograr frutos do processo educacional.

Carver (1974; in Himmel, 1979), estabelece uma distinção entre as dimensões psicométricas e edumétricas de um teste, entretanto, chega a assinalar que, de alguma forma, todos os testes proporcionam medidas das diferenças individuais nessas duas dimensões. São ressaltadas suas características psicométricas quando procuram refletir diferenças estáveis entre os indivíduos, e edumétricas quando refletem um crescimento do próprio indivíduo.

Nesse sentido, Popham (1978) indica que um teste refere-se a critério quando fornece uma informação de ganhos individuais em objetivos educacionais especificos, expressando uma mudança percebida em termos de desempenho e não apenas uma mudança de posição relacionada à situação dos outros alunos. 
McNeil (1981) concebe o teste referenciado a critério diretamente ligado às habilidades aprendidas com a finalidade de especificar o que os alunos dominam, ou seja, o conjunto de saberes que o aluno apresenta, em comparação aos objetivos totais do currículo.

Os testes devem indicar pontos em que os alunos necessitam tratamentos educacionais e apontar as áreas em que o aluno está apto a prosseguir.

O que se busca, no caso, não é uma variabilidade nos resultados para discriminar posições, mas uma medida que possa estimar o que foi aprendido com o processo pedagógico.

Isaac e Michael (1983) vêem o teste referenciado a critério como capaz de mostrar o desempenho particular do aluno numa área de conhecimento a partir de uma base de objetivos específicos do currículo. Eles ainda entendem a referência a critério como uma evolução tecnologica voltada para a medida de situações muito específicas; como uma medida de um domínio específico do conteúdo curricular previamente selecionado e contemplado pelos objetivos de ensino, os quais serão medidos por uma certa quantidade de itens; vêem também como um processo de análise de resultados, cuja interpretação pode ser dada em termos de percentuais de desempenho, a partir de critérios previamente definidos.

A validade de conteúdo é o mais importante requisito dos testes referenciados a critério, e seus itens devem ser dotados de sensibilidade para aquilatar mudanças individuais numa situação particular de instrução.

A sistematização de um processo de avaliação cuja medida seja interpretada com base no padrão de desempenho, requer a consideração de que todos os alunos devem atingir o mínimo explicitado como critério em todos os objetivos significativos que compõem o domínio.

Dessa forma a delimitação do domínio de ensino sugere o padrão esperado c, nesse caso, a construção de testes foge aos procedimentos dos testes normativos, pois devem prever, como resultado, escores máximos para todos os alunos (De Cecco, 1968).

A especificação do domínio com todos os objetivos que the são inerentes, é o passo inicial para a construção de instrumentos 
referenciados a critério. $\mathrm{O}$ domínio delimitado deve ser conciso para servir de orientação à construção dos itens e de base à análise de resultados, devendo circunscrever uma homogênea e abrangente classe de aprendizagens para permitir identificar itens que são adequados ou não, para medi-lo (Popham, 1975).

Na construção dos itens para a composição do instrumento de medida, deve-se cuidar principalmente que haja correspondência entre a prova e o total de objetivos que the deu origem, garantindo-se, assim, validade de conteúdo. O que importa no caso é que os itens ensejem situações significativas, através das quais os alunos possam demonstrar os conhecimentos indicados nos objetivos relevantes, previamente selecionados.

Nesse enfoque, o instrumento de medida tem em vista obter resultados que traduzam o domínio da aprendizagem em qualquer campo do conhecimento, mediante um padrão de desempenho aceitável, que é o critério. Não faz sentido aqui preocupações com a variabilidade de resultados $\mathrm{e}$ as consequientes discriminação e ordenação de alunos; cumprindo apenas estabelecer quem atingiu ou não atingiu o critério.

Num sistema de avaliação baseado no padrão absoluto de desempenho, que considera a fixação de um nível de aceitabilidade, o critério, e a correspondência dos itens a uma listagem de objetivos significativos pré-selecionados, a notação do aluno seria expressa em termos de cada aluno ter ou não atingido o nível mínimo prédeterminado. A complementação numérica representaria o percentual de atingimento dos objetivos medidos, ou o índice de ganho quando relacionado a situações de testagem pré-pós ou recuperação (Gronlund, 1979).

Haveria, portanto, mediante os objetivos medidos e o nível de aceitação admissível, preocupação apenas em indicar o sucesso ou insucesso do aluno, conforme apresentasse ou não o desempenho estabelecido no critério. Ficaria para o segundo plano a fixação do percentual atingido ou do índice de ganho, que tem importância apenas no sentido de fornecer ao aluno a dimensão exata de sua posição face ao critério absoluto da totalidade dos objetivos. Uma sistematização desse tipo de avaliação com a análise de seus resultados, encontra-se em anexo. 


\section{Norma ou critério: o que está acontecendo na escola?}

Concordamos com Himmel (1979), ao afirmar que a diferenciação feita por Caver (1974) das dimensões edumétricas e psicométricas é mais clara do que a dicotomia norma/critério. Para ela, também as provas realizadas em sala de aula com o fim de ressaltar diferenças individuais contrapõem-se aos enfoques de aprendizagem que acreditam que a maioria dos alunos deve alcançar a maioria dos objetivos, dependendo de uma boa adequação do processo de ensino às necessidades e possibilidades do aluno.

Rigorosamente em nossas escolas nenhum padrão é utilizado para interpretação dos resultados de aprendizagem. Usualmente as provas são construídas sem nenhum cuidado técnico e seus itens dizem respeito apenas aos conteúdos ensinados. "Esse processo foge inteiramente à prática de avaliação por medidas baseadas em critérios que supõem um processo de ensino a partir de objetivos predeterminados"(Vianna, 1980, p.6).

Embora saibamos que o sistema utilizado pelas escolas atende apenas à necessidade de atribuição de notas, cumprindo, portanto, uma finalidade exclusivamente somativa e burocrática, é forçoso reconhecer que o aspecto de referência a norma, no que diz respeito ao uso de estatísticas, não se faz presente. Por essa razão, as notas e mençōes apresentadas perdem por completo o significado, pois não dispõem de uma base para intcrpretação.

Essas constatações levam-nos a acreditar que a avaliação que está sendo feita não é satisfatória ao desenvolvimento do processo educacional, pois não serve para verificar a existência de prérequisitos, detectar problemas de aprendizagem e caracterizá-los, e nem para verificar a correspondência entre o desempenho obtido e o padrăo desejado. Por outro lado, também não informa sobre a posição relativa dos indivíduos no grupo, sobre o nível de desempenho do grupo mediante algum critério e nem, ao menos, indica o que foi realmente medido pelos instrumentos aplicados.

Isto significa dizer que o que estamos fazendo em avaliação é completamente arbitrário e não obedece a nenhum critério e que esse fato coloca-nos diante da necessidade imediata de discutir o tema 
avaliação, aprofundar os conhecimentos sobre o assunto e entender que as informações obtidas devem servir para especificar os erros que precisam ser corrigidos na ação pedagógica, a fim de proporcionar uma melhoria no rendimento escolar.

A notação que expressa o rendimento do aluno, seja nota ou conceito, deve ter um significado conhecido, compreendido e aceito por todos os interessados. Isso, nós sabemos, não acontece. Os pais, os alunos, os professores e, por extensão, os administradores desconhecem o real significado do "A" ou "D", " 50 " ou " 80 " que é colocado nas fichas dos alunos. A explicação desse fato é óbvia: em nossas escolas é desconhecido o que as provas e os testes medem; seus resultados não revertem a uma crítica do processo de ensino nem do instrumento de medida em si. Não se tem um critério fixo para interpretação dos resultados que são classificatórios, mas totalmente inconsistentes, pois não são utilizadas as técnicas necessárias para a especificação do desempenho de cada aluno em função do desempenho do grupo.

Uma ciassificação supõe um critério normativo e desse modo, o A, B, C, D e E deviam ser explicados forçosamente pelas unidades de desvios-padrão em relação à media do grupo e os números, 10,20 , $50, \ldots 100$ deviam exprimir a ordem percentílica, ou seja, o ponto abaixo do qual está um percentual " $x$ " de alunos da turma. Nesse caso, caberia atentar para a validade de conteúdo de prova, a fidedignidade de seus resultados, as estimativas de índices de dificuldade e discriminação dos itens para uma criteriosa análise da prova e de seus resultados.

Uma avaliação de resultados útil à melhoria do rendimento escolar responderia a questões como:

- Qual a situação de cada indivíduo em relação aos objetivos fixados?

- Qual o desempenho do grupo de alunos face ao critério fixado?

- Quais os objetivos medidos pelo instrumento que se constituíram em dificuldades para os alunos?

- Quais os itens do teste que não se mostraram adequados?

- Quão produtivo foi o trabalho da classe, incluindo professor e aluno considerando os critérios estabelecidos? 
- Quais os alunos que devem ser recuperados e exatamente em que objetivos?

- Que mudanças o professor deve fazer para prosseguir no seu trabalho?

- Que orientações o professor deverá fornecer aos alunos?

- Os resultados obtidos são aceitáveis?

- Até que ponto o livro didático, os exercícios desenvolvidos, o tempo disponível e o desempenho docente foram responsáveis pelos resultados obtidos?

- Que providências serão pedidas à administração $\mathrm{e}$ às famílias dos alunos?

Esses são exemplos de alguns pontos a considerar na avaliação de resultados com vistas a melhorar o ensino, o estudo e a promover uma aprendizagem mais significativa.

"As medidas referenciadas a critério, vão ao encontro desses propósitos de proporcionar um melhor rendimento escolar"(Vianna, 1980 , p.14). Tendo em vista que, no momento atual, é urgente considerar o problema da recuperação de deficiências de aprendizagem, torna-se muito importante a adoção de um sistema de avaliação baseado nessas medidas, como uma contribuição efetiva para alunos e professores.

\section{3 - CONTEXTUalizando a Matemática no CuRRÍculo ESCOLAR}

\section{O ensino e a aprendizagem da matemática: algumas considerações}

Recentes estudos relacionados ao desempenho em matemática foram realizados pelo Departamento de Pesquisas Educacionais da Fundação Carlos Chagas no pcríodo 87/89 e consistiram de pesquisas mais amplas sobre avaliação do rendimento de alunos de escolas de $1^{\circ}$ grau da rede pública; avaliação do rendimento de alunos de escolas de $1^{\circ}$ grau da rede privada, avaliação do rendimento escolar de alunos da $3^{\mathrm{a}}$ série do $2^{\circ}$ grau (Vianna, 1989a; Vianna, 1989b)

A escola pública de $1^{\circ}$ grau não tem conseguido dotar o alunado do mínimo proposto nos programas estabelecidos para a disciplina 
matemática; tal é, pelo menos, o que os alunos demonstram ao responder aos itens de teste de desempenho. Para os professores, as causas do insucesso são: deficiência alimentar; preparo inadequado nas $1^{\text {a }}$ séries e conseqüentemente falta de base; falta às aulas; desinteresse dos pais e sua pequena escolaridade; sucessivas transferências; número de disciplinas na $5^{\mathrm{a}}$ série; problemas emocionais e necessidade de trabalhar para ajudar a família. Para os administradores das escolas as causas do insucesso são: pobreza absoluta dos alunos; falta de participação da família; número de alunos por sala; inadequação entre idade e escolaridade; evasão; conflito entre o currículo e as necessidades dos alunos; falta de assistência pedagógica para o professor; deficiência na própria formação pedagógica; desalento, falta de perspectiva e falta de profissionalismo docente; ausência de autonomia das escolas e até insegurança pública.

O que se constata é que as médias de acertos em testes de 30 questões versando sobre os temas básicos dos programas de $1^{\mathrm{a}}, 3^{\mathrm{a}}, 5^{\mathrm{a}} \mathrm{e}$ $7^{\mathrm{a}}$ séries são desanimadoras. $\mathrm{Na} 1^{\mathrm{a}}$ e $3^{\mathrm{a}}$ séries, as médias de acerto ficam em 17,64 e 17,74 respectivamente. Na $5^{\text {a }}$ série a média fica em 9,06 questões e na $7^{a}$ série atinge 12,74 .

A partir do julgamento de que o programa proposto para $01^{\circ}$ grau é necessário e viável e tendo-se como certo que as provas aplicadas têm validade de conteúdo, isto é, que estão em perfeito acordo com os temas e as séries para as quais foram propostas, o que se pode depreender é que os "resultados refletem menos o fracasso individual do que o comprometimento de todo o processo educacional", responsável pelo domínio de conhecimentos e habilidades no campo da matemática (Vianna, 1989a, p. 110).

$\mathrm{Na}$ escola de $2^{\circ}$ grau, os dados da avaliação do rendimento escolar da última série dão conta de que a situação em matemática não difere muito da encontrada no $1^{\circ}$ grau. Os alunos não mostram um desempenho sequer razoável nos testes aplicados em escolas técnicas, de ensino geral e de preparação para o magistério, nas cidades de Salvador, Fortaleza, Curitiba e São Paulo. Pasma constatar que os alunos de magistério, futuros responsáveis pelo ensino inicial de $1^{\circ}$ grau, apresentem os desempenhos mais baixos da amostra (Vianna, 1989c). 
Em pesquisa realizada pelo INEP-UFPB (1982), foi analisada a influência das variáveis sexo e atitude na aprendizagem dos conteúdos de matemática. Esse também foi um estudo nacional que, entre outras coisas, constatou que o nível de aprendizagem atingido é quase sempre o de simples computação, ensejando o questionamento do que poderia ser feito pela escola para dar condições ao aluno de atingir um nível que permita a transferência de aprendizagem para a resolução de problemas em matemática.

As análises realizadas nos resultados dos testes e nas opiniões de professores revelam que há absoluta falta de compreensão das estruturas matemáticas e, geralmente, pela pressa em vencer os programas - princípio e fim da escola, ao que parece - a aprendizagem é mal iniciada, "voltada para a memorização e para o domínio de cálculos, sem a necessária compreensão das operações (p.9).

É consenso admitir-se como domínio básico em matemática, a realização das operações de adiçāo, subtração, multiplicação e divisão com números naturais, frações decimais e inteiros; o cálculo e utilização de medidas, razõcs, proporções, porcentagens, raízes e potências; conhecimento de álgebra e geometria; levantamento de estimativas e aproximações; julgamento de resultados; formulação e resolução de problemas; seleção de meios adequados para a solução de problemas e utilização de conceitos elementares de probabilidade e estatística.

Esse elenco de aprendizagens é exigido para o ingresso no ensino superior. A nosso ver, introduz-se, assim, um viés no ensino básico, que contribui para o desinteresse e o acúmulo de dificuldades, pois deixa de ser prioritário aquilo que seria útil e significativo ao desenvolvimento imediato do aluno, para se privilegiar o que seria necessário para a formação de $3^{\circ}$ grau, à qual chegam poucos e não necessariamente aos cursos que requisitam maiores fundamentos de matemática. Esse é, portanto, um aspecto que deve ser analisado para que o $1^{\circ}$ e $2^{\circ}$ graus de ensino tenham função em si e não em razäo de um $3^{\circ}$ grau.

O ensino de matemática deve apresentar uma seqüência natural, ou seja, o programa de um grau de ensino deve apoiar-se no programa já desenvolvido, ou melhor, assimilado e aprendido no grau anterior. Essa mesma lógica é válida para as séries, semestres e bimestres 
letivos. O desrespeito a essa sequência é um dos responsáveis "pela atitude de rejeição e temor em relação à educação matemática" (INEPUFPB, p. 9).

Dessas consideraçōes vale ressaltar que seria necessário, principalmente no campo da matemática, estabelecer os mínimos necessários para cada grau de ensino e insistir para que sejam realmente atingidos por todos os alunos. Esses mínimos necessários comporiam os objetivos de ensino de matemática e poderiam observar a seqüência de aprofundamento apresentado por Wilson (1971) e categorizada nos níveis de computação, compreensão, aplicação e análise.

O nível de compreensão mostra a necessidade de conhecer conceitos, transpor os elementos do problemas de uma forma de linguagem para outra, além de ler e interpretar problemas. Essas idéias vão ao encontro da opinião dos professores de matemática que apontaram como aspectos mais interessantes a serem avaliados, a habilidade para resolver problemas, a habilidade de compreensão de textos e o conhecimento de conteúdos específicos (SENAI-SP, 1984a). Em outro estudo, também realizado no SENAI para diagnosticar as deficiências de aprendizagem acumuladas no $1^{\circ}$ grau, constatou-se, através da aplicação de um teste de conhecimentos básicos, que apenas $30 \%$ dos alunos da $1^{a}$ série do $2^{\circ}$ grau apresentaram rendimentos superiores a $50 \%$, sendo aquele percentual aumentado para $60 \%$ após estudos de revisão (SENAI-SP, 1984b).

Fica a idéia de que o diagnóstico das dificuldades, aliado a um trabalho de recuperação de aprendizagem, são essenciais para a melhoria do rendimento da aprendizagem, direito legítimo de cada aluno do sistema escolar. As limitações e a pobreza do processo de avaliação que a impedem de cumprir o papel de servir de base a decisões de melhoria c recuperação das aprendizagens contribuem, de certa forma, para que a matemática torne-se o elemento estrangulador do sistema escolar.

O estudo internacional realizado por Husen (1967), comparando o desempenho em matemática em diversos países, levantou a hipótese de que a dificuldade implícita na aprendizagem da matemática não influencia o desempenho do aluno e que a habilidade matemática, seria resultante de uma composição entre habilidade 
espacial, numérica, verbal e computacional, aliada ainda a fatores culturais, aspirações e oportunidades oferecidas pela escola e pelo mercado de trabalho.

Na bibliografia relativa à aprendizagem matemática, os pontos estudados recaem predominantemente nas variáveis sexo, classe social, aptidão para matemática, atitudes, horas dedicadas ao estudo. Alguns deles atentam para a competência dos professores e métodos de ensino. Autores com Piaget (1972), Bruner (1973) e Gagné (1973), segundo Ragazzi (1976) enfatizam o proprio processo de raciocínio matemático, suas necessidades e dificuldades específicas. Não se encontra, entretanto, referência a estudos sobre os efeitos do processo de avaliação no desenvolvimento do ensino, nem de sua relação com a aprendizagem geral ou, da matemática, em particular.

\section{O papel da matemática no currículo}

O lugar ocupado pela matemática no currículo escolar justificase pela necessidade de desenvolver atividades práticas que envolvem aspectos quantitativos ligados a grandezas, contagens, medidas e cálculos que integram a realidade $\mathrm{e}$ pela necessidade de desenvolvimento do raciocínio lógico, incluindo a capacidade de abstrair, generalizar e extrapolar.

Esses dois aspectos são fundamentais para caracterizar o papel a ser desempenhado pela matemática e devem ser considerados inseparáveis na composição do que vai ser aprendido. Essa situação de equilíbrio constitui um verdadeiro desafio ao professor, que se vê pressionado entre as necessidades de resolução de problemas práticos e aquelas que dizem respeito à ultrapassagem da experiência sensível.

Essa transcendência do que é imediatamente percebido forma a base para a autonomia intelectual. É necessário compreender que esta autonomia, além de não ser dada exclusivamente pela escola, também não o é, dentro da própria escola, proporcionada apenas pela matemática. Entretanto, é preciso reconhecer que a ela cabe um destaque especial como agente da construção e desenvolvimento do raciocínio.

Para atender a essa orientação, os temas básicos para estudo como, Números e Geometria, não podem prescindir de um terceiro que 
diz respeito a Medidas e que serve de elemento de ligação útil para a construção do conceito de número e para a formação da arquitetura das relações geométricas. Para o estudo de número a sugestão é "partir tanto de contagens como de medidas, sem se ater às propriedades estruturais... trocando uma sistematização prematura por uma abordagem mais rica em significados " (Miguel et alii, CENP/306, 1986, P.4). Já no estudo de Geometria, sugere-se "partir da manipulação dos objetos, do reconhecimento de suas formas, de sua caracterização e propriedades... e somente no final do percurso aproximar-se de uma sistematização provisória a ser desenvolvida no $2^{\circ}$ grau “ (Miguel et alii, CENP/306, 1986, p. 4).

Assim sendo, os temas apresentados na proposta curricular deveriam ser articulados para atender à meta de servir tanto de ferramenta para o trabalho diário como de fator de desenvolvimento do raciocínio; concretamente, isto seria validado na percepção de proporcionalidade, equivalência e semelhança, através da qual os dados pudessem ser observados não somente em sua seqüência, mas em sua interdependência, como um recurso à reflexão, elaboração de hipóteses e resolução de problemas.

Os estudos avaliativos de aprendizagem em matemática, no contexto do projeto global de avaliação da aprendizagem, para o sistema SENAI - SP

Alguns estudos avaliativos de matemática ocorreram no SENAI de forma mais ou menos continuada, no período compreendido entre 1980 e 1986. Neles, pudemos constatar que os alunos de $2^{\circ}$ grau, iniciam o curso com amplas defasagens de aprendizagem no programa relativo ao $1^{\circ}$ grau. Pudemos verificar também que um plano de revisão desses conteúdos ajuda a melhorar um pouco essa aprendizagem, mas as deficiências continuam em pontos específicos do programa.

Este fato, a princípio muito acentuado pelo próprio teste, por demais extenso, foi atenuado no último estudo com a utilização de testes de quarenta (40) questões. Neste, também, ficou evidenciado que, o crescimento dos alunos no programa de revisão é pequeno e sua 
contribuição para os resultados de aprendizagens do programa do $2^{\circ}$ grau é da mesma forma pouco acentuada.

Nesse mesmo período, precisamente a partir de 1983, outro projeto da Divisão de Currículos e Programas do SENAI-SP e do qual fizemos parte, levantou dados, sistematizou diretrizes e propôs uma metodologia de planejamento e avaliação do ensino para a rede SENAI-SP (Pecher, et alii, 1987).

Esse processo, iniciado em 1983, levantou entre professores e técnicos ligados ao ensino, em todas as escolas, idéias e sugestões que refletissem suas formas de atuação, seus anseios e expectativas, principalmente no que concerne aos problemas ligados à avaliação da aprendizagem, considerados por todos como pontos críticos do ensino.

A análise desses dados, compatibilizados com objetivos, estratégias, formas e finalidades da avaliação, bem como sistemas de notação, aprovação e recuperação, e ainda aliados às peculiaridades de um sistema de formação profissional com suas funções próprias no contexto social, deu condiçбes para o levantamento de algumas idéias consensuais, básicas e norteadoras de um processo de avaliação inteiramente vinculado ao planejamento do ensino e que se constituíram em diretrizes para o trabalho.

Dessas diretrizes surgiu uma metodologia tanto quanto possível ligada a uma avaliação baseada em critério, a que se sentiu ser mais apropriada para atender ao sistema, sem descuidar as necessidades dos professores e alunos.

O documento contendo essas diretrizes e respectiva metodologia foi divulgado como proposta de trabalho (SENAI-SP, 1985b). Em 1986, procedemos a uma implementação da proposta em algumas escolas, sabendo de antemão que dois fatores seriam graves limitantes da sua prática. $\mathrm{O}$ primeiro diz respeito à questão do tempo disponível dos professores. Näo dá para pensar que a implantação de um processo de avaliação, baseado em critério ou mesmo em norma, possa acontecer sem demanda de trabalho adicional do professor. Esse tempo não poderia ser inferior a um terço daquele indicado à sala de aula sem que houvesse comprometimento da qualidade do trabalho. $\mathrm{O}$ segundo diz respeito à capacitação do professor na área específica de avaliação. Torna-se impossível a realização desse trabaiho sem essa capacitação técnica que envolve compreensão das relações entre 
objetivos de ensino e resultados de aprendizagem; entre instrumentos de medida da aprendizagem, objetivos e estratégias de ensino; entre análise de resultados e decisões globais de planejamento do ensino, execução de programas e recuperação da aprendizagem.

Nesse contexto, nada mais oportuno do que testar, com as condições imprescindíveis de tempo e capacitação, os efeitos de uma metodologia de avaliação baseada em critério.

Dessa forma, ao mesmo tempo em que se estava pondo em prática a metodologia integrada de planejamento e avaliação do ensino em algumas escolas e efetuando estudos de correlação de aprendizagem de matemática nas escolas de $2^{\circ}$ grau, ocorreu-nos escolher uma delas, que estivesse fora da implementação da metodologia de avaliação por critério na aprendizagem de matemática contando com as condições, que julgamos sine qua non, de tempo e capacidade técnica.

Assumimos esse trabalho paralelo de forma efetiva e mais elaborada, de modo a se constituir no projeto de pesquisa para a organização do estudo que ora se apresenta.

\section{4 - JUSTIFICANDO E OBJETIVANDO O ESTUdO}

A forma natural do surgimento do problema que nos propusemos a estudar, sua ligação e pertinência a um contexto maior, abrangendo a aprendizagem de matemática e o processo de avaliação, parece-nos por si só uma razoável justificativa para esse trabalho. Entretanto, outros fatores contribuíram para fortalecê-la.

No campo da avaliação, acreditamos que a quase absoluta inexistência de pesquisas, principalmente no tocante à relação entre o seu processo e a quantidade e qualidade da aprendizagem, é um fator considerável para se investir esforços nesse sentido.

Por outro lado, acresce-se a importância de que se reveste a aprendizagem de matemática dentro e fora da escola, sendo quase sempre forte determinante, não só do sucesso pessoal, mas do fator que ocasiona o grande volume da evasão e repetência a que se assiste no sistema escolar.

Outro aspecto diz respeito ao papel desempenhado pela matemática no crescimento do raciocínio lógico, conforme se acredita. 
Essa base de raciocínio se constitui em fator primordial para aprendizagens mais significativas, duradouras e em níveis mais profundos, seja qual for o campo do conhecimento.

A par disso, estamos certos de que uma boa avaliação será aquela que proporcione um conjunto de direcionamentos necessários a essas aprendizagens, razão que nos levou a relacionar formas de avaliação à qualidade de aprendizagem.

O objetivo principal do trabalho empreendido foi o de comparar dois processos de avaliação, sendo um referenciado a norma e outro referenciado a critério, a fim de investigar sua aplicabilidade e verificar até que ponto eles influenciam os resultados da aprendizagem.

Mais especificamente, o presente trabalho propôs-se a verificar: 1) a existência de diferenças significantes no grau de aprendizagem de matemática que possam ser relacionadas aos diversos tipos de avaliação;

2) se a atitude em relação à matemática $\mathrm{e}$ a inteligência influenciam a aprendizagem dessa disciplina.

\section{5 - Explicttando a Metodologia do Trabalho \\ O campo de pesquisa - Escola SENAI Suíço-Brasileira - (CFP 1.15)}

O Serviço Nacional de Aprendizagem Industrial - SENAI - foi criado em 22 de janeiro de 1942 pelo Decreto-Lei Federal n ${ }^{\circ} 4448$. Constitui uma entidade jurídica de direito privado com sede e foro na Capital da República. Ainda que vinculado ao Ministério do Trabalho, sua organização e direção competem à Confederação Nacional da Indústria.

Em São Paulo, o Departamento Regional - SENAI/DR-SP - de acordo com o Regimento aprovado pelo Decreto Federal n ${ }^{\circ} 494$, de 10 de janeiro de 1962, mantém na forma da legislação específica, unidades de ensino de $2^{\circ}$ grau e supletivo, estando ligado à Federação da Indústrias do Estado de São Paulo - FIESP.

Organizado e estruturado para atender às necessidades de formação profissional, a partir dc uma forte vinculação com as 
empresas industriais e da realização de levantamentos periodicamente renovados da força de trabalho, o SENAI-SP, no final da década de 60 , percebeu que algumas mudanças haviam se processado na área de mecânica e identificou a necessidade de suprir a indústria de uma mão de obra cuja absorção dar-se-ia na área de produção de máquinas, instrumentos e aparelhos de precisão (Gonçalves, 1987).

Assim, em 1971, com a assinatura de um termo de Colaboração com a Fundação Sú́ç̧a de Assistência ao Desenvolvimento Técnico Swiss contact - , começava a concretizar-se a idéia de formar o Técnico em Mecânica de Precisão. A Escola SENAI "SuíçoBrasileira"- CFP 1.15, recebeu sua $1^{2}$ turma em 1973.

Este centro de formação profissional ministra ensino regular de $2^{\circ}$ grau e tem por objetivo a formação do Técnico em Mecânica de Precisão propiciando a Educação Geral e a Formação Profissional e possibilitando ao aluno, ingressar na força de trabalho e/ou prosseguir estudos.

A escola está situada em Santo Amaro, em terreno de $18.530 \mathrm{~m}^{2}$, possuindo $10.475 \mathrm{~m}^{2}$ de área construída. Além das salas de aula, campos de esporte e área para refeitório, possui oficinas que reproduzem o ambiente da indústria e também laboratórios de Ótica, Instrumentos Mecânicos, Eletrônica, Metrologia, Física, Planejamento de Produção, Pneumática, Hidráulica, Periféricos, Solda, Tratamento Térmico, Galvanoplastia e Ensaios Mecânicos.

O curso de Mecânica de Precisão é ministrado em período integral, durante quatro anos letivos, ocorrendo, no último, o estágio supervisionado. Até 1986, haviam concluído o curso 754 alunos, após o cumprimento de uma carga horária total de 5.688 horas, sendo 1.860 horas de disciplinas da Parte Comum e 3.828 horas em disciplinas da Parte Diversificada. O estágio supervisionado abrange 590 horas, sendo 190 na escola e 400 em empresas para as quais o aluno é encaminhado.

Em 1987, a Escola Suíço-Brasileira, em avaliação feita pela École Technique Sainte-Croix, ligada à Swiss contact, mereceu destaque quanto à sua organização, eficiência de trabalho pedagógico, conteúdo dos programas e suficiência dos equipamentos.

Com vistas à próxima década, a Escola Suíço-Brasileira está se preparando para atender a evolução reclamada atualmente pela área de 
Mecânica na direção do Sistema Flexível de manufatura, passando pelo CAD/CAM, Robótica e Comando Numérico por computação (Gonçalves, 1987).

\section{Os Alunos Pesquisados - Grupos controle, norma e critério - caracterização}

Em termos gerais, os grupos de alunos da pesquisa assemelham-se muito nos aspectos que podem ser vistos conjuntamente na Tabela 1 que apresenta a amplitude, a média e a mediana dos dados referentes à idade, situação sócio-econômica, média de classificação e nota de matemática na prova de seleção.

Tabela 1

Idade, Renda familiar, resultados da seleção e nota em Matemática dos Grupos Controle, Norma e Critério - CFP 1.15

\begin{tabular}{|c|c|c|c|}
\hline Variáveis & $\begin{array}{c}\text { Controle Grupo } 1 \\
\mathrm{~N}=31\end{array}$ & $\begin{array}{c}\text { Norma Grupo } 2 \\
\mathrm{~N}=31\end{array}$ & $\begin{array}{c}\text { Critério Grupo } 3 \\
\mathrm{~N}=28 \\
\end{array}$ \\
\hline 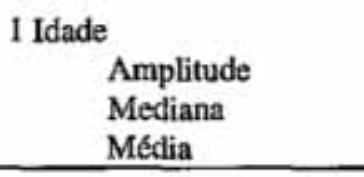 & $\begin{array}{c}\text { (Anos) } \\
14-19 \\
16 \\
15,97 \\
\end{array}$ & $\begin{array}{c}\text { (Anos) } \\
14-20 \\
16 \\
15,97 \\
\end{array}$ & $\begin{array}{c}\text { (Anos) } \\
14-20 \\
16 \\
15,97 \\
\end{array}$ \\
\hline $\begin{array}{l}2 \text { Renda } \\
\qquad \begin{array}{l}\text { Amplitude } \\
\text { Mediana } \\
\text { Média familiar }\end{array}\end{array}$ & $\begin{array}{c}(\mathrm{CZ} \$) \\
190-7.200 \\
1.462 \\
1.924,71 \\
\end{array}$ & $\begin{array}{c}(\mathrm{C} 7 \$) \\
279-4.380 \\
1.000 \\
1.478 \\
\end{array}$ & $\begin{array}{c}(\mathrm{Cz} \$) \\
310-6.000 \\
1.200 \\
1.730 .89 \\
\end{array}$ \\
\hline $\begin{array}{l}3 \text { Resultados Globais da } \\
\text { seleção } \\
\text { Amplitude } \\
\text { Mediana } \\
\text { Média } \\
\end{array}$ & $\begin{array}{c}\text { (Pontos) } \\
41-78 \\
64 \\
61.3 \\
\end{array}$ & $\begin{array}{c}\text { (Pontos) } \\
43-80 \\
64,5 \\
64,3 \\
\end{array}$ & $\begin{array}{c}\text { (Pontos) } \\
44-79 \\
64,5 \\
64 \\
\end{array}$ \\
\hline $\begin{array}{l}\text { 4 Notas de Matemática } \\
\text { na seleção } \\
\text { Amplitude } \\
\text { Mediana } \\
\text { Média }\end{array}$ & $\begin{array}{c}\text { (Pontos) } \\
08-28 \\
23 \\
21,9 \\
\end{array}$ & $\begin{array}{l}\text { (Pontos) } \\
12-30 \\
24 \\
23,56 \\
\end{array}$ & $\begin{array}{c}\text { (Pontos) } \\
12-29 \\
24 \\
22,7 \\
\end{array}$ \\
\hline
\end{tabular}

Fonte: Fichas individuais do arquivo do setor de orientação educacional.

Como se pode observar, os dados referentes aos aspectos considerados, principalmente quando apresentados em termos de mediana, indicam grande similaridade entre os grupos. Isso ocorreu nitidamente com relação à idade $\mathrm{e}$ aos resultados globais da seleção. A 
maior discrepância foi verificada no tocante à renda familiar que, todavia, tal como indicada pela mediana, chega a se aproximar, mostrando que, também no aspecto econômico, os grupos se assemelham.

\section{Os instrumentos utilizados}

O Pré/Pós-teste e o teste de retenção - O teste utilizado na pré e pós testagem para averiguar o desempenho dos Grupos Controle, Norma e Critério é um teste de matemática elaborado pela equipe técnica do SENAI, já aplicado e portanto validado em pesquisa anterior.

Trata-se um teste de quarenta questões cobrindo 25 objetivos relativos à matemática da últimas séries do $1^{\circ}$ grau e constantes do programa de revisão de conteúdo adotado no SENAI no primeiro semestre do $2^{\circ}$ grau.

Esse mesmo teste foi aplicado para verificar a retenção da aprendizagem após o final do ano letivo.

Os testes intermediários - Cinco testes foram aplicados no período em que foi realizada a pesquisa. As formas de análise de seus resultados e as informaçōes daí provenientes é que possibilitaram a diferenciação nos tipos de avaliação a que cada grupo estava submetido. Os testes intermediários contemplaram as partes dos programas vencidas passo a passo e, na prática, serviram para compor as notas bimestrais dos alunos. Eles se constituíram assim, em 5 testes de aprendizagem elaborados pelo professor e composto de 19, 20, 23, 14 e 14 questões, do primeiro ao último, respectivamente.

Teste de conteúdos do segundo grau - Para medir a aprendizagem dos diversos grupos no programa referente aos conteúdos iniciais do segundo grau, foi aplicado um teste, elaborado também pela equipe central do SENAI e já utilizado em estudos anteriores. Trata-se de um teste de quarenta questões cobrindo o domínio de 23 objetivos do programa.

Questionário para professores e roteiro de entrevista com alunos - Para coletar dados referentes ao grupo de professores de $2^{\circ}$ grau do SENAI, bem como levantar opiniōes a respeito do ensino e da avaliação da matemática, foi utilizado um questionário com doze itens, 
visando obter o maior número possível de informações que possibilitou uma visão mais abrangente dos problemas ligados ao ensino da matemática.

Para os alunos foi utilizado um roteiro de entrevista, também visando uma complementação de dados para melhor compreensão dos aspectos a serem analisados e discutidos.

A escala Ragazzi - Para medir a atitude dos alunos com relação à matemática foi utilizada a escala construída por Ragazzi (1976). Ela parte da consideração de que o componente atitudinal é constituído de elementos cognitivos, afetivos e comportamentais.

Trata-se de uma escala de atitudes face à matemática, de tipo Likert, com vinte itens internamente consistentes sendo dez favoráveis e dez desfavoráveis.

O teste DAT - O teste de Aptidões Específicas (D A T), elaborado por G. K. Bennet et alii (1959) foi escolhido para ser utilizado nesse estudo devido à possibilidade que apresenta de coletar dados a respeito das "... muitas habilidades que os indivíduos possuem em graus diferenciados que segundo Thurstone (apud Bennet et alli $1959 ;$ p.4), compõem a inteligência humana.

O teste DAT compõe-se de provas de Raciocínio Verbal, Habilidade Numérica, Raciocínio Abstrato, Relações Espaciais, Raciocínio Mecânico, Rapidez e exatidão, incluindo também o uso da Linguagem , abrangendo ortografia e sentenças. Essas provas procuram descrever a potencialidade de cada sujeito para aprender uma série de disciplinas escolares ou desempenhar tarefas profissionais formando, entretanto uma bateria integrada.

\section{A seqüência do trabalho}

Delimitado o problema e especificados os objetivos passamos a escolher o campo para efetivar o estudo e a selecionar os grupos com os quais seriam experienciados os dois tipos de avaliação propostos: Norma e Critério.

Num primeiro momento, solicitamos à Diretoria Regional do SENAI-SP autorização para que a pesquisa fosse realizada no âmbito da escolas de $2^{\circ}$ grau do SENAI e, mais especificamente, no CFP 1.15, Escola Suíço-Brasileira de Mecânica de Precisão, pelas razões já 
anteriormente apresentadas. A autorização nos foi concedida pelo Dr. Paulo Ernesto Tolle, Diretor Regional da Instituição e a partir dela seguimos um cronograma de trabalho.

Faz-se necessário salientar que a Escola em apreço colocou-se inteiramente à nossa disposição e nela pudemos trabalhar contando com o apoio do pessoal docente, técnico e administrativo.

Através de sorteio, as turmas ficaram distribuídas da seguinte forma:

Grupo 1 - Grupo Controle, vivenciando o processo de avaliação usual da Escola.

Grupo 2 - Vivenciando o processo de avaliação baseado em Norma Critério.

Grupo 3 - Vivenciando o processo de avaliação baseado em

Os grupos foram exaustivamente acompanhados pela pesquisadora durante o ano letivo de 1986, cabendo à mesma, seguir o horário de aula previsto para a disciplina matemática, nas três turmas e assessorar o professor no planejamento e desenvolvimento das atividades de avaliação, incluindo a análise dos resultados particularmente realizada por aquela profissional e discutida com todos os participantes, a cada momento. Durante o ano de 1987 a atuação da pesquisadora se fez de forma pouco frequiente apenas para atender à necessidade de aplicação de testes, efetuar entrevistas ou buscar dados complementares.

Os momentos de avaliação foram os seguintes:

$\mathbf{1}^{\circ}$ - Aplicação do pré-teste de matemática na primeira aula a fim de verificar as dificuldades remanescentes do primeiro grau e obter um parâmetro para avaliação dos resultados ao final da revisão do programa do $1^{\circ}$ grau.

Esse teste foi aplicado logo após o primeiro contato com a turma. Nesse primeiro encontro foram dadas todas as informações sobre a pesquisa e sua dinâmica, além de ter sido explicada a necessidade $\mathrm{e}$ a função do pré-teste.

Na segunda aula os resultados do pré-teste foram apresentados aos os três grupos separadamente, tendo-se o cuidado de mostrar os objetivos medidos e os acertos obtidos, atentando-se às diferenças 
existentes entre uma análise feita com base em norma e uma outra feita com base em critério.

As tabelas com os resultados obtidos $e$ analisados foram afixadas em um quadro mural ficando à disposição dos alunos, para consulta e levantamento de questões.

Ainda nessa segunda aula, o grupo 3 que vivenciou a avaliação por critério foi alertado de que o programa a ser desenvolvido tinha $\mathrm{em}$ vista alcançar uma série de objetivos que the foram apresentados e que, de alguma forma, já estavam contemplados pelo pré-teste. Esse programa também ficou à disposição dos alunos durante todo o período.

$2^{\circ}$ - Aplicação da Escala Ragazzi para verificar as atitudes favoráveis e desfavoráveis com relação à Matemática. Essa escala foi respondida pelos diversos grupos na segunda semana do semestre. Os dados foram computados e apresentados aos alunos, com a explicação para os diversos grupos de que seus resultados apenas ordenavam os alunos pelo maior ou menor interesse, disposição e facilidade para aprender matemática.

$\mathbf{3}^{\circ}$ - Aplicação de testes intermediários. A cada bimestre os alunos dos três grupos foram submetidos a provas para verificar o andamento do programa e para cumprir a necessidade regimental da atribuição de notas. As provas eram iguais ou muito semelhantes para os três grupos. Todas foram feitas com base nos objetivos delimitados no plano de curso. Entretanto, a partir da análise de resultados diferenciada para os Grupos Norma, Critério e Controle é que se operacionalizava a diversidade de informações prestadas aos grupos de alunos. Dessa forma, durante todo o período de revisão os alunos do Grupo Critério obtiveram as mais variadas informações sobre objetivos atingidos ou não; questões adequadas ou inadequadas; resultados positivos ou negativos da turma como um todo e de cada aluno em particular, além de indicações de objetivos a atingir ou pontos determinados a revisar. Enquanto isso o Grupo Norma recebia os resultados em termos de questōes acertadas ou não em termos de divisão dos alunos em A, B, C e D, subgrupos formados com base na mediana e nos quartis, além da indicação de recuperação para o subgrupo D. O Grupo Controle segundo o esquema usual da escola, 
recebia os seus resultados em termos de acerto ou erro em cada questão e a consequiente nota corresponde ao total de acertos.

Dessa forma efetivava-se a diferenciação operada pelos diversos tipos de avaliação em que procurávamos levantar os dados para mostrar a importância do sistema de informação largamente enriquecido pela análise de resultados da avaliação por critério, trazendo como consequêencia uma melhoria da aprendizagem dos alunos com implicações na qualidade da própria percepção do processos de aprender e na crítica das variáveis desse processo.

$4^{\circ}$ - Aplicação do pós-teste de matemática aconteceu na última aula do período de revisão que se desenvolveu durante todo o $1^{\circ}$ semestre. Com esse teste procurava-se saber os ganhos de cada aluno e de cada turma para estabelecer as possíveis diferenças de resultados.

Esse teste foi igual ao pré-teste aplicado na primeira aula. Seus resultados foram apresentados aos grupos com as informações completas como aconteceu com o pré-teste.

Com esses resultados deu-se por encerrado o acompanhamento dia-a-dia e os contatos, a partir de então, tornaram-se bastante espaçados. Dessa forma o passo seguinte apenas aconteceu no início do $2^{\circ}$ ano letivo quando os alunos já desenvolviam o programa de $2^{\circ}$ grau.

$5^{0}$ - Aplicação do teste de retenção. Esse teste aplicado em fevereiro de 1987 foi em tudo igual ao pré e pós-teste. Com ele procurou-se saber o que os alunos haviam retido de tudo o que haviam aprendido durante a revisão do programa do $1^{\circ}$ grau.

$6^{\circ}$ - Aplicação de Teste de aprendizagem referente ao programa de matemática do $2^{\circ}$ grau desenvolvido no segundo semestre. Esse teste foi aplicado no mês de abril de 1987. Com ele buscou-se mais um indicador da permanência da diferenciação entre as turmas.

$7^{\circ}$ - Por fim, no $2^{\circ}$ semestre de 1987 , foi aplicado o teste D. A. T. aos três grupos de alunos. $\mathrm{O}$ teste foi aplicado em duas sessões, uma no período da manhã e outra no período da tarde.

Ao lado desses levantamentos, a pesquisadora procurou ainda ouvir, em entrevistas semi-estruturadas, alguns alunos que fizeram parte do estudo e, também, através de questionários levantar dados dos professores de $2^{\circ}$ grau da rede SENAI-SP. Com isso procuraram-se dados que pudessem complementar aqueles já levantados. 
Em resumo foi seguido o cronograma abaixo:

\begin{tabular}{|c|c|}
\hline ATIVIDADES & REALIZAÇĀO \\
\hline Aplicação do pré-teste & fevcreiro - $1986\left(1^{\prime \prime}\right.$ semana $)$ \\
\hline Aplicaçāo da Escola Ragazzi & fevereiro - $1986\left(2^{2}\right.$ semana $)$ \\
\hline Aplicaçāo dos testes intermediários & março/junho - 1986 \\
\hline Aplicação do pos-teste & junho - $1986\left(4^{n}\right.$ semana $)$ \\
\hline Aplicaçäo do teste de retenção & fevereiro - $1987\left(2^{a}\right.$ semana $)$ \\
\hline Aplicação do teste de $2^{\circ}$ grau & abril - 1987 ( $1^{\text {" semana })}$ \\
\hline Aplicaçăo do Teste D.A.T & novembro - 1987 ( $4^{a}$ semana) \\
\hline Entrevistas corn alunos & novembro/dezembro - 1988 \\
\hline
\end{tabular}

Quadro 1 - Cronograma das atividades principais da pesquisa realizada.

Escola SENAI Suiço-Brasileira (CFP 1.15)

\section{6 - DESCREVENDo os RESUltados}

\section{Do pré-teste}

Como anteriormente foi descrito o pré-teste de matemática constou de uma prova de quarenta questöes visando medir vinte e cinco objetivos básicos do programa de primeiro grau, uma vez que o semestre inicial do primeiro ano do segundo grau nas Escola SENAI é dedicado a uma revisão desses conteúdos. A prova foi aplicada às diversas turmas que compuseram este estudo, no início de fevereiro, exatamente no primeiro dia de aula. Os resultados gerais dos três grupos nesse teste inicial encontram-se na tabela a seguir.

Tabcla 2

Resultados percentuais dos grupos Controle, Norma e Critério, no pré-teste de matemática considerando 0 acerto nas questões e o domínio dos objetivos. Escola SENAI 1.15

\begin{tabular}{llll}
\hline \multicolumn{1}{c}{ Resultados do Pré-teste } & Controle & Norma & Critério \\
\hline Percentual de acertos ( questōes) & 67,35 & 65,9 & 58,13 \\
\hline Percentual de domf́nio (objetivos) & 58,08 & 60,03 & 48,8 \\
\hline
\end{tabular}

Fonte: Mapas gerais de resultados do pré-teste de matemática. 
A comparação dos percentuais médios de acerto nas questões, aponta um melhor resultado do grupo Controle sobre os grupos Norma e Critério. Já no que se refere ao domínio, sobressai o grupo Norma. Os dados gerais do pré-teste parecem apontar para um desempenho predominantemente mais fraco do grupo Critério, nessa fase do estudo.

\section{Dos testes intermediários - (Avaliação por Norma e Critério)}

A fase correspondente à aplicação dos testes intermediários constitui-se no próprio tipo de avaliação desenvolvido com as turmas que integraram este estudo.

A forma diferenciada de analisar os resultados dos testes, sistematizar as informações daí extraídas e estabelecer o fluxo de informaçōes aos alunos, caracteriza a avaliação por Norma, Critério ou outro tipo qualquer.

Assim sendo, o Grupo Controle não teve nenhum tratamento específico. Seus testes eram apenas corrigidos, pontuados e os resultados anotados no diários de classe, após tiradas as dúvidas provenientes da correção ou apontadas as dificuldades mais freqüentes. Era o sistema usual da escola. Por esta razão apresentamos nesse tópico, apenas os resultados dos Grupos Norma e Critério.

Durante o semestre foram aplicados cinco testes referentes às diversas partes do programa desenvolvido, conforme mostra a tabela a seguir.

Tabela 3

Percentual médios de acertos nas questôes dos testes intermediários nos Grupos Norma e Critério - CFP 1.15

$1^{\mathrm{A}}$ série do $2^{\circ}$ grau.

\begin{tabular}{cccc}
\hline TESTE & ACERTO & $\begin{array}{c}\text { NORMA } \\
\text { Percentuais Médios }\end{array}$ & $\begin{array}{c}\text { CRITÉRIO } \\
\text { Percentuais Médios }\end{array}$ \\
\hline 1 & 78,0 & 68,2 \\
\hline 2 & 71,7 & 70,9 \\
\hline 3 & 79,7 & 69,3 \\
\hline 4 & 78,3 & 70,4 \\
\hline 5 & 83,3 & 83,2 \\
\hline
\end{tabular}

Fonte: Mapas de resultados dos Grupos Norma e Critério 
Comparando os resultados dos dois grupos, nesse período em que estiveram submetidos a tipos diferenciados de avaliação - (Norma e Critério) - podemos observar, que o Grupo Norma iniciou o curso numa posição superior a do Grupo Critério. No segundo teste, enquanto o Grupo Norma sofreu um declínio, o Grupo Critério deu sinais de mudança qualitativa no desempenho. No terceiro teste podese observar que o Grupo Norma voltou a crescer enquanto o Grupo Critério caiu um pouco em relação ao teste anterior. No quarto teste, enquanto o Grupo Norma decai um pouco, o Grupo Critério retoma o crescimento. No teste cinco, os Grupos Norma e Critério apresentam um bom crescimento. 5 e 12,8 pontos percentuais na média de acertos, respectivamente.

\section{Do pós-teste}

O pós-teste de matemática, igual ao pré-teste, constou de quarenta questões para medir vinte e cinco objetivos do programa do $1^{\circ}$ grau, revisado durante o primeiro semestre, na primeira série do $2^{\circ}$ grau.

Tabela 4

Resultados percentuais dos grupos Controle, Norma e Critério, no pós-teste de matemática considerando $o$ acerto nas questöes e o domínio dos objetivos. Escola SENAI 1.15

\begin{tabular}{llll}
\hline Resultados do pós-teste & Controle & Norma & Critério \\
\hline Percentual de acertos (questōes) & 81,3 & 86,6 & 81,8 \\
\hline Percentual de domínio (objetivos) & 75,1 & 82,1 & 76,4 \\
\hline
\end{tabular}

Fonte: Mapas gerais de resultados do pós-teste de matemática.

Os dados comparativos dos Grupos Controle, Norma e Critério, no pós-teste de matemática, mostram uma certa similaridade nos resultados dos alunos tanto no que se refere as questôes quanto aos objetivos.

Nas questões os percentuais médios de acerto situaram-se acima de $80 \%$. Nela constata-se $81,3 \%$ para o Grupo Controle 81,8 para o Grupo Critério e 86,6 para o Grupo Norma. Verifica-se uma diferença 
de 4,8 percentuais entre os Grupos Norma e critério e de 5,3 entre o primeiro e Grupo Controle.

Nos objetivos, os resultados seguiram a mesma ordem , ficando a média percentual do Grupo Norma em $82,1 \%$ seguida do Grupo Critério com 76,4 e do Grupo Controle com 75,1\%

\section{Dos índices de ganho dos Grupos Controle, Norma e Critério - Relação pré/pós teste}

Relacionando os dados pré-pós teste estabelecemos os ganhos relativos obtidos pelos Grupos Controle, Norma e Critério, dados pela relação entre o ganho real e o maior ganho possível nas questões e nos objetivos. No Grupo Controle, o crescimento da turma atingiu o índice de 0,41 , tanto no acerto das questões quanto no domínio. O Grupo Norma apresentou crescimento igual a 0,64 no acerto de questōes e 0,55 no domínio de objetivos. O Grupo critério atingiu um crescimento de 0,53 e 0,54 , respectivamente.

Tabela 5

Ganhos médios relativos dos grupos Controle, Norma e Critério, em matemática considerando o acerto nas questões e o domínio dos objetivos. Escola SENAI 1.15

\begin{tabular}{lccc}
\hline \multicolumn{1}{c}{ Ganhos relativos } & Controle & Norma & Critério \\
\hline No acerto das questōes. & 0,41 & 0,64 & 0,53 \\
\hline No domínio dos objetivos & 0,41 & 0,55 & 0,54 \\
\hline
\end{tabular}

Fonte: Mapas gerais de resultados do pós-teste de matemática.

\section{Do ganho relativo dos Grupos Controle, Norma e Critério - Relação pós teste / retenção}

$O$ teste de retenção que serviu para verificar a permanência da aprendizagem foi o mesmo aplicado para medir os resultados da revisão (pós-teste). A partir dele, querfamos estimar o quanto da aprendizagem realizada permaneceu ou se alterou com o tempo, embora em curto espaço. Essa nova aplicação do teste ocorreu no início do primeiro semestre do $2^{\circ}$ ano, exatamente nas primeiras aulas do mês de fevereiro. 
'THbela 6

Ganhos médius relativos dos grupos Controle, Nortma c Critéto, em matemética considerando o acerto nas questīes e o doulítio dos ofjetivos. Escola SENAI 1.15

\begin{tabular}{llll}
\hline Ganbus redatlwos & Controle & Nordir & Criterio \\
\hline No acerto das questóes. & 0,05 & $-0,01$ & $-0,09$ \\
\hline No don'́nio dos objetivos & 0,07 & $-0,07$ & $-0,23$ \\
\hline
\end{tabular}

Fonte: Mapns gerais de resultados do pos-teste de metemática.

A tabela mostra que os Grupos Norma e Criterio obtiveram resultados negativos enquanto o Grupo Controle apresentou um crescimento. Observa-se, também, que as perdas relativas do Grupo Critério foram maiores do que as do Grupo Norma. Esse fato pode suscitar a idéia de que a suspcosão do tratamento dado aos Grupos Criterio e Norma - traduzido en informaçōes baseadas ent análises de resultados de aprendizagen a partir do alesempenho do Grupo (Avaliaçăo por Norma) ou do desempenho individual no domínio de objetivos (Avaliação por Critério)-de qualquer forma está relacionada ao processo de perda, mormente quando se constata que o Grupo Critério provido de informaçōes mais completas durante o tratamento, apresentou um bom ercscimento para em seguida, privado destas informaçōes, sofrer maiores perdas.

\section{7 - Constatando OS Resultados}

A fim de verificar a significância das diferenç̧as observadas nos Grupos Controle, Norma e Critério nas diversas variáveis consideradas, foram efetuadas análises estatísticas dos dados. Utilizamos para essas analises as provas de Friedman, Wilcoxon, Kruskal Wallis e o coeficiente de Correlação de Postos de Spcarman.

Optatnos pela utilizaçăo da estatistica găo-paramétrica pelo fato de o nilvel de medida da varífvel dependente ser ordinal, e de näo se conhecer a forma de sua distribuiçăo. $O$ nível de significância adotado Para todas as comparaçōes foi de 0,05 . 


\section{Avaliação do Desempenho em matemática - Comparação intragrupos}

O desempenho em matemática foi medido através de provas nas situações pré, pós, retenção e $2^{\circ}$ grau. Os resultados desses testes foram analisados intragrupos por meio das provas Friedman para verificar se os diferentes resultados dependeram das condições sob as quais foram obtidos e de Wilcoxon para verificar o sentido e o valor das diferenças entre os vários resultados tomados dois a dois. Neste caso foi utilizado a prova unilateral, uma vez que era previsto o sentido das diferenças (Siegel, 1979, p. 84 e 189).

Tabela 7

Medianas dos resultados dos diversos testes de matemática dos Grupos Controle, Norma e Critério. SENAI - SP $1^{a}$ série do $2^{\circ}$ grau.

\begin{tabular}{l|cccc}
\hline \multicolumn{1}{c|}{ Testes } & \multirow{2}{*}{ Prup-teste } & Pós-teste & $\begin{array}{c}\text { Teste de } \\
\text { retençäo }\end{array}$ & $\begin{array}{c}\text { Teste de } \\
\mathbf{2}^{\circ} \text { grau }\end{array}$ \\
\hline Controle & 28 & 33 & 34 & 27 \\
\hline Norma & 28 & 36 & 36,5 & 32 \\
\hline Critério & 21 & 33 & 33 & 33 \\
\hline
\end{tabular}

Fonte: Resultados dos testes aplicados

As medianas da Tabela 7 mostraram uma diferença maior para o Grupo Critério, entre o pré e o pós teste e uma tendência à estabilização , neste patamar. Enquanto isso, os Grupos Controle e Norma cresceram até o teste de retenção e decaíram no teste de $2^{\circ}$ grau.

Essas diferenças de resultados foram analisados através da prova de Friedman e seus resultados são apresentados na Tabela 8.

Tabela 8

Resultados da Prova de Friedman referentes aos testes de desempenho em matemática dos Grupos Controle, Norma e Critério. SENAI - SP $1^{\circ}$ série do $2^{\circ}$ grau.

\begin{tabular}{l|ccc|c}
\hline & Resultados & & & \\
\cline { 1 - 4 } Grupos & G. L & $\mathbf{X r}^{2}$ & $\mathbf{X}^{2} \mathbf{C}$ & \multicolumn{1}{c}{ Interpretacão } \\
\hline Controle & 3 & 19,69 & 7,82 & sig a 0,001 \\
\hline Norma & 3 & 42,17 & 7,82 & sig a 0,001 \\
\hline Critério & 3 & 39,44 & 7,82 & sig a 0,001 \\
\hline
\end{tabular}


Os resultados da Prova de Friedman apresentados na Tabela 8 indicam que os desempenhos dos Grupos Controle, Norma e Critério sofreram variações decorrentes das condições sob as quais esses desempenhos foram obtidos ou seja: os Grupos Controle, Norma e Critério apresentaram desempenhos diferenciados conforme foram testados nas situações de pré e pós teste, retenção e teste de $2^{\circ}$ grau. Podemos concluir, portanto, que há diferenças significantes entre os desempenhos e que estes dependem das diferentes condições em que foram medidos, considerando cada grupo de per si.

Constatadas as diferenças entre os desempenhos nas quatros situaçōes testadas cabe então, determinar o sentido dessas diferenças e a sua significância através da Prova de Wilcoxon, cujos resultados constam das tabela a seguir.

Tabela 9

Resultados da Prova de Wilcoxon referentes ao desempenho dos Grupos Controle, Norma e Critério no pré e pós-teste, no teste de retençäo e de conhecimento do $2^{\circ}$ grau.

\begin{tabular}{llll}
\hline $\begin{array}{c}\text { Grupos } \\
\text { Desempenhos }\end{array}$ & Controle & Norma & Critério \\
\hline Pós $>$ Pré & sig** & sig*** & sig** \\
\hline Pós $>$ Ret & n. sig & n. sig & n. sig \\
\hline Pós $>2^{\circ}$ grau & sig** & sig** & sig** \\
\hline Ret $>$ Pré & sig*** & sig** & sig** \\
\hline $2^{\circ}$ grau $>$ Pré & n. sig & n.sig & sig** \\
\hline Ret $>2^{\circ}$ grau & sig** & sig** & n. sig \\
\hline *** sig a 0,01 & & &
\end{tabular}

A Tabela 9 mostra que, para os Grupos Controle, Norma e Critério, os desempenhos no pós-teste foram significantemente maiores do que no pré-teste e no teste de conhecimento do $2^{\circ}$ grau; os desempenhos no teste de retenção foram maiores do que os obtidos no pré-teste e não foram menores do que os demonstrados no pós-teste, indicando que não houve perdas consideráveis e que alguns ganhos ainda puderam ser obtidos através do programa de $2^{\circ}$ grau $\mathrm{em}$ desenvolvimento. Em duas situaçōes o Grupo Critério mostrou-se diferente dos demais: o desempenho no teste de conhecimento do $2^{\circ}$ 
grau foi maior do que o obtido no pré-teste e não foi menor do que o demonstrado no teste de retenção, conforme verificou-se nos Grupos Controle e Norma, indicando realmente uma estabilização daquele grupo ao nível obtido no pós-teste.

\section{Avaliação do Desempenho èm matemática - Comparação intergrupos}

Para verificar a significância das diferenças entre os Grupos Controle, Norma e Critério nos diversos testes de matemática foi utilizada a Prova de Kruskal Wallis que permite uma comparação entre várias amostras independentes (Levin, 1978).

Tabela 10

Resultado da Prova de Kruskal Wallis referentes ao desempenho dos Grupos Controle, Norma e Critério no pré e pós-teste, no teste de retenção e de conhecimento do $2^{\circ}$ grau

\begin{tabular}{|c|c|c|c|c|}
\hline \multicolumn{5}{|c|}{ Resultados } \\
\hline Testes & G.L & $\mathrm{H}$ & $\mathrm{X}^{2} \mathrm{C}$ & Probabilidade \\
\hline Pré-Teste & 2 & 4,11 & 5,99 & 0,128 \\
\hline Pós-Teste & 2 & 4,38 & 5,99 & 0,112 \\
\hline Retenção & 2 & 4,04 & 5,99 & 0,133 \\
\hline $2^{\circ}$ grau & 2 & 4,76 & 5,99 & 0,092 \\
\hline
\end{tabular}

Os resultados da Prova de Kruskal Wallis apresentados na Tabela 10 mostram valores encontrados $(\mathrm{H})$ inferiores a $\mathrm{X}^{2} \mathrm{C}$. As probabilidades superiores à adotada em todo esse processo de análise permitem concluir que os desempenhos dos diversos grupos não foram estatisticamente diferentes, tanto no pré-teste como no pós, no teste de retenção no de $2^{\circ}$ grau. 


\section{Avaliaçäo da atitude}

Os escores da escala de atitude em relação a matemática dos Grupos Controle, Norma e Critério foram transformados em índices cujas medianas constam na tabela 11 .

Tabela 11

Medianas da escala de atitude em relaçäo à matemática nos Grupos Controle, Norma e Critério

\begin{tabular}{ccc}
\hline Controle & Norma & Critério \\
\hline 0,28 & 0,36 & 0,30 \\
\hline
\end{tabular}

Esses índices indicam atitude positiva, porém com reduzida intensidade. As diferenças constatadas forma submetidas à Prova de Kruskal Wallis para comparação intergrupos e verificação da significância das diferenças apresentadas.

Tabela 12

Resultados da Prova de Kruskal Wallis referente aos índices de atitude em relaçäo à matemática dos Grupos Controle, Norma e Critério

\begin{tabular}{ccccc}
\hline G. $\mathbf{L}$. & $\mathbf{H}$ & $\mathrm{X}^{2} \mathrm{C}$ & Probabilidade & Interpretação \\
\hline 2 & 2,85 & 5,99 & 0,24 & n. sig \\
\hline
\end{tabular}

Pelos resultados da Prova de Kruskal Wallis, apresentados na tabela 12 pode-se afirmar que não há diferenças significantes na atitude em relação à matemática nos Grupos Controle, Norma e Critério.

\section{Avaliação da inteligência}

Os dados dos diversos subtestes do D.A.T. dos Grupos Controle, Norma e Critério, aparecem na tabela 13 em termos de medianas dos percentis. 
Tabela 13

Medianas dos percentis dos diversos testes de aptidão dos Grupos Controle, Norma c Critério.

\begin{tabular}{lccc}
\hline \multicolumn{1}{c}{ Grupos } & & & \\
\hline Testes & Controle & Norma & Critério \\
\hline Raciocínio Verbal & 10 & 30 & 35 \\
\hline Habilidade Numérica & 60 & 60 & 70 \\
\hline Raciocínio Mecânico & 70 & 75 & 65 \\
\hline Raciocínio Abstrato & 45 & 45 & 50 \\
\hline Relações Espaciais & 65 & 65 & 65 \\
\hline Rapidez e Exatidão & 75 & 75 & 65 \\
\hline Ortografia & 65 & 20 & 70 \\
\hline Sentenças & 10 & 15 & 15 \\
\hline
\end{tabular}

Fonte: Resultados dos testes aplicados

Observa-se que em raciocínio verbal os Grupos Norma e Critério apresentaram melhor desempenho; em ortografia, o Grupo Critério foi melhor do que o grupo Norma e quase se igualou ao Grupo Controle. Nos demais casos, as diferenças säo pequenas. Os Grupos Controle e Norma tiveram resultados acima do percentil 70 em raciocínio mecânico e rapidez e exatidão. No Grupo Critério o maior percentil (70) ficou em ortografia, sendo o maior entre os grupos, o mesmo acontecendo em habilidade numérica, embora sem atingir 70 de mediana.

Constatadas essas diferenças buscou-se comprovar sua significância a partir da Prova de Kruskal Wallis para comparação de amostras independentes (Levin, 1978). 
Tabela 14

Resultados da Prova de Kruskal Wallis referentes ao percentis obtidos pelos Grupos Controle, Norma e Critério nos diversos testes de aptidão

\begin{tabular}{lccccc}
\hline \multicolumn{1}{c}{ Grupos } & & & & & \\
\hline Testes & G.L. & H & $\mathrm{X}^{2} \mathrm{C}$ & Probabilidade & Interpretação \\
\hline Raciocínio Verbal & 2 & 2,608 & 5,99 & 0,361 & n. sig \\
\hline Habilidade Numérica & 2 & 3,400 & 5,99 & 0,252 & n. sig \\
\hline Raciocínio Mecânico & 2 & 1,332 & 5,99 & 0,542 & n. sig \\
\hline Raciocínio Abstrato & 2 & 3,650 & 5,99 & 0,226 & n. sig \\
\hline Relações Espaciais & 2 & 0,908 & 5,99 & 0,976 & n. sig \\
\hline Rapidez e Exatidäo & 2 & 3,953 & 5,99 & 0,248 & n. sig \\
\hline Ortografia & 2 & 5,107 & 5,99 & 0,062 & n. sig \\
\hline Sentenças & 2 & 0,883 & 5,99 & 0,942 & n. sig \\
\hline
\end{tabular}

A Tabela 14 mostra que os Grupos Controle, Norma e Critério são indiferenciados nas diversas aptidões medidas pelo subteste do D.A.T. Pode-se constatar dessa forma sua homogeneidade e principalmente chama atenção os melhores resultados para Habilidade Numérica, Raciocínio Mecânico, Relações Espaciais e Rapidez e Exatidão (Tabela 13).

Isso se deve talvez ao processo de seleção a que foram submetidos os alunos tendo em vista o curso a que se destinaram Técnico em Mecânica de Precisão. Tudo faz crer que esses alunos compõem uma amostra com características específicas no que diz respeito às aptidōes intelectuais.

\section{Correlações}

Para completar o quadro de análise estatística foram efetuados cálculos de correlação de Spearman a fim de verificar as correlações significantes entre inteligência $\mathrm{e}$ atitude $\mathrm{e}$ atitude $\mathrm{e}$ ganhos. 
A Tabela 15 mostra as correlações entre inteligência e ganhos dos Grupos Controle, Norma e Critério. Pode-se verificar que há correlação positiva significante entre o índice de ganho do Grupo Controle e os resultados dos subtestes de Habilidade Numérica, Raciocínio Mecânico e Raciocínio Abstrato, significando que os alunos que obtiveram melhores resultados nesses testes obtiveram maiores índices de ganho.

O mesmo não aconteceu com os Grupos Norma e Critério, pois, no Grupo Norma a correlação significante ocorreu entre ganhos e Relaçōes Espaciais e para o Grupo Critério foi significante a correlação entre ganhos e Rapidez e Exatidão. Ou seja, no Grupo Norma os alunos que obtiveram melhores resultados em relaçöes espaciais apresentaram maiores índices de ganho. Já no Grupo Critério os alunos que obtiveram maiores ganhos foram os que se destacaram no teste de rapidez e exatidão.

Tabela 15

Correlação entre inteligência e desempenho em termos de índice de ganho dos Grupos Controle, Norma e Critério.

\begin{tabular}{lccc}
\hline \multicolumn{1}{c}{ Ganhos } & & Grupos & \\
\hline Inteligência & Controle & Norma & Critério \\
\hline Racioć́nio Verbal & 0,16 & 0,20 & $-0,23$ \\
\hline Habilidade Numérica & $0,59^{*}$ & 0,35 & 0,19 \\
\hline Raciocínio Mecânico & $0,39^{*}$ & $-0,09$ & $-0,06$ \\
\hline Raciocínio Abstrato & $0,43^{*}$ & 0,04 & 0,19 \\
\hline Relaçőes Especiais & 0,26 & $0,42^{*}$ & 0,08 \\
\hline Rapidez e Exatidão & 0,22 & $-0,33$ & $0,43^{*}$ \\
\hline Ortografia & 0,11 & $-0,33$ & 0,04 \\
\hline Sentenças & 0,08 & $-0,12$ & $-0,11$ \\
\hline sig 0,05 & & &
\end{tabular}

A Tabela 16 mostra as correlações entre inteligência e atitude. 
Tabela 16

Correlaçōes entre inteligência e atitude nos Grupos Controle, Norma e Critério.

\begin{tabular}{lccc}
\hline \multirow{2}{*}{ Inteligência } & \multicolumn{3}{c}{ Grupos } \\
\cline { 2 - 4 } & Controle & Norma & Critério \\
\hline Raciocínio Verbal & $-0,39^{*}$ & 0,08 & $-0,01$ \\
\hline Habilidade Numérica & 0,08 & 0,18 & 0,14 \\
\hline Raciocínio Mecânico & 0,27 & 0,05 & 0,22 \\
\hline Raciocínio Abstrato & 0,08 & 0,12 & $0,43^{*}$ \\
\hline Relações Especiais & 0,17 & 0,33 & 0,13 \\
\hline Rapidez e Exatidăo & 0,08 & $-0,13$ & 0,17 \\
\hline Ortografia & 0,06 & $-0,28$ & $-0,31$ \\
\hline Sentenças & 0,22 & $-0,29$ & $-0,33$ \\
\hline
\end{tabular}

* sig a 0,05

Duas correlaçöes foram significantes: no Grupo Controle, a correlação negativa entre atitude e Raciocínio Verbal, demonstrando que os alunos deste Grupo que melhor se desempenharam no teste de Raciocínio Verbal foram os que apresentaram índices mais baixos de atitude positiva em relação à matemática. No Grupo Critério, a correlação significante indica que os alunos de melhor desempenho em Raciocínio Abstrato foram os que apresentaram maiores índices de atitude positiva em relação à Matemática.

A Tabela 17 mostra as correlações entre atitude e ganhos.

Tabela 17

Corrclações entre atitnde e desempenhos em termos de índices de ganhos dos Grupos Controle, Norma e Critério

\begin{tabular}{ccc}
\hline Controle & Norma & Critério \\
\hline 0,27 & 0,13 & 0,13 \\
\hline
\end{tabular}


Para os três Grupos, conforme mostra a Tabela 17 as correlações não foram significantes.

As diversas correlaçöes apresentadas nas Tabelas 15,16 e 17 são baixas, mesmo aquelas que se mostraram significantes. $\mathrm{O}$ maior coeficiente foi 0,59 , entre habilidade numérica e f́ndice de ganho em Matemática, verificado no Grupo Controle. Entretanto, essa correlação que parece tão natural ser alta, no caso em pauta, indica uma eficiência preditiva de pouco mais de $19 \%$. Isso quer dizer que mais de $80 \%$ da variação dos ganhos do Grupo Controle pode ser explicada por outros fatores não ligados à habilidade numérica.

\section{8 - RETOMANDO o ESTUdo E OS ResUltados, À GUISA DE CONCLUSÃO}

A aprendizagem de matemática dentro e fora da escola revestese de importância por ser forte determinante de sucesso pessoal e por ocasionar grande quantidade de evasão e repetência dentro do sistema escolar. Por outro lado, é comum destacar-se o papel desempenhado pela matemática no desenvolvimento do raciocínio, fator primordial para as aprendizagens mais abrangentes em qualquer campo do conhecimento.

Dentro do sistema escolar o processo de avaliação da aprendizagem é a base decisória que promove, infirma e ratifica, tanto o caminho do sucesso como o da mediocridade e da sensação de incompetência que fatalmente desembocam na repetência e na evasão.

Esse fato dá ao processo de avaliação da aprendizagem um significado que extrapola o campo estritamente pedagógico ao qual se deveria circunscrever, tornando-o um fator de promoção ou de alijamento dos indivíduos dentro do sistema social. A partir dessa consideração, a avaliação da aprendizagem assume um papel de extrema importância dentro do sistema escolar, chegando a inquietar todos aqueles comprometidos com a educação.

Apesar dessa importância e das angústias que provoca, o processo de avaliação é pouco compreendido em sua totalidade e pouco estudado em suas implicaçöes práticas. A inexistência de pesquisas nesse campo, principalmente tentando relacioná-lo à 
qualidade dos resultados da aprendizagem, foi o fator básico para direcionar esforços para esse estudo.

Partimos de um objetivo central voltado a investigar a possibilidade de aplicar, em situação regular de ensino, uma forma estruturada e coerente de avaliar a aprendizagem com base nos padrões teóricos que envolvem a metodologia de análise de resultados por norma e critério. Ligado a essa preocupação tornou-se fundamental verificar se um processo de avaliação assim desenvolvido, seria capaz de influenciar os resultados de aprendizagem. Além desses pontos, dois outros foram objetos de atenção e dizem respeito à influência da atitude e da inteligência na aprendizagem. Isso porque é consenso entre educadores e leigos, que aprender, principalmente aprender bem matemática, significa ser inteligente e que o gosto e o interesse $\mathrm{em}$ aprender é muitas vezes tão relevante que é capaz de minimizar a insuficiência da aptidão.

Basicamente procuramos constatar a existência de diferenças significantes no grau de aprendizagem de matemática que pudessem estar relacionadas aos diversos tipos de avaliação e verificar se a inteligência e a atitude em relação à matemática influenciam a aprendizagem dessa disciplina.

A especificação desses objetivos encontra respaldo numa série de proposições que integram a bibliografia consultada.

Admitimos que um planejamento abrangente reflete uma filosofia de trabalho e deve contemplar os diversos passos do processo pegagógico propiciando uma comunicação útil que informe sobre o que será avaliado, quais as linhas seguidas na execução da avaliação e os critérios que basearão a interpretação dos resultados (Depresbiteris et alii , 1984; Brito, 1987).

A finalidade do ensino é ajudar os alunos a atingir os objetivos constantes do plano de ensino que evidencia, também, conteúdos, estratégias ,materiais de ensino, formas, instrumentos e critérios de avaliação. Esses dados interrelacionados efetivam a comunicação e propiciam as bases para a análise crítica do processo (Wang, 1977; De Cecco, 1968). Um sistema de avaliação implantado nesses moldes concorre para o aprimoramento do processo de ensino (Vianna, 1980), constituindo-se em elemento unificador capaz de aperfeiçoá-lo como 
um todo desde as suas bases até os resultados finais, incluindo o próprio processo avaliativo.

A avaliação baseada em norma tem em vista descobrir diferenças individuais e possibilidades de sucesso em situações de aprendizagem. Ela identifica pessoas de capacidades diferenciadas, mas é questionável para avaliar o contexto curricular por não revelar o que os programas ensinaram nem os problemas que alteraram a realização da aprendizagem (McNeil, 1981).

A avaliação baseada em critérios procura saber se cada aluno conseguiu os frutos do processo de ensino, fornecendo informação sobre ganhos individuais expressos em mudança de desempenho e não em termos de posição (McClelland, 1973; Popham, 1978), indicando pontos em que os alunos necessitam tratamentos educacionais e áreas em que o aluno está apto a prosseguir (McNeil, 1981; Isaac e Michael, 1983).

Em nossas escolas esses padrões não são utilizados para interpretar resultados de aprendizagem. $O$ processo de avaliação não verifica a existência de pré-requisitos; não detecta problemas de aprendizagem; não caracteriza falhas nem verifica a correspondência entre o desempenho obtido e o padrão desejado. Também não informam sobre a posição relativa dos indivíduos no grupo; sobre o nível de desempenho do grupo como um todo e nem ao menos indica o que foi realmente medido pelos instrumentos aplicados (Vianna, 1980).

O desempenho em geral resulta da aptidão e do interesse (Anastasi, 1977) e o desempenho em matemática é influenciado tanto por variáveis cognitivas como afetivas sendo que estas resultam quase sempre de experiências específicas de aprendizagem (Aiken et alii, 1961; Ragazzi, 1976; Natalício, 1967; Skemp, 1971; Dienes, 1973). A atitude em relação à matemática é positivamente correlacionada à habilidade numérica, além de outros fatores intelectivos (Aiken et alii, 1961). Sendo favorável, a atitude em relação à matemática é fator importante para um bom desempenho (Schofield, 1981; Aiken, 1970, 1976; Wolf e Blixt, 1981), pois o interesse ou gosto por essa disciplina liga-se ao empenho para aprendê-la (Suydan e Weaver, 1975), da mesma forma que a habilidade para a matemática, liga-se a um bom desempenho dessa disciplina (Young et alii, 1979). 
Várias pesquisas realizadas com abrangência local, nacional e internacional, dão conta das dificuldades encontradas pelos alunos de $1^{\circ} \mathrm{e} 2^{\circ}$ graus e procuram apresentar algumas explicaçőes para esse fato repetidamente constatado (SENAI-SP, 1981, 1984b, 1985b e 1987; INEP-UFPB, 1982; Vianna e Gatti, 1988; Vianna, 1989a, 1989b e 1989c; Husen, 1967). Entretanto, nesses estudos não são apontadas alternativas para solucionar esses problemas que têm origem em fatores muito diversificados, tanto no âmbito escolar, como no âmbito social. O que se constata é que, até hoje, não foram adotadas políticas educacionais que possam, pelo menos no campo restrito da escola e do desenvolvimento curricular, permitir uma mudança no sentido de efetivar uma melhoria de aprendizagem na área da matemática.

Do nosso ponto de vista um processo abrangente de avaliação seria capaz de prover, por meio de um sistema adequado de comunicação, as bases para decisão conjunta de reorientação da ação pedagógica, por parte de professores e alunos co-responsáveis e coparticipantes do desenvolvimento do processo e, nesse caso, os mais interessados em alcançar um bom desempenho. A nosso ver a avaliação baseada em critério é, no momento, a mais adequada para proporcionar bases coerentes a decisões pedagógicas com vistas à melhoria de ensino, bastando, para tanto, instruir o professorado na utilização desse procedimento e dar-lhe tempo suficiente para efetuar as análises necessárias; promover ampla discussão com os alunos; planejar e promover recuperação imediata. A avaliação baseada em norma, cuja filosofia é parte integrante do sistema escolar, mas na realidade, apenas utilizada em processos classificatórios realizados por algumas instituições, também proporcionam informações importantes, apesar de sua preocupação fundamental ser separar grupos de desempenhos.

Partindo dessas considerações, procuramos verificar se essas formas de avaliação podiam ser operacionalizadas de maneira a adaptar-se à realidade de nossas escolas e se o seu desenvolvimento seria viável para o dia-a-dia dos professores e alunos, trazendo-lhes benefícios em termos de poder assumir seu trabalho pedagógico e direcioná-lo rumo à solução das dificuldades de aprendizagem.

O programa ou plano de ação pedagógica para esse estudo, foi estruturado de forma a atender aos três grupos de alunos (Controle, 
Norma e Critério) que participaram do mesmo. As diferenças básicas apareciam nos parâmetros utilizados para análise de resultados bem como nas informações daí decorrentes e nas conseqüentes decisões tomadas (Gronlund, 1976).

O estudo se baseou principalmente nessa diferenciação que procurou ser bastante rigorosa em termos de atender à teoria de medida a à técnica de análise dos resultados; sua duração entretanto, pareceu muito reduzida para introduzir mudanças mais profundas. Esse estudo concretizou-se a partir de análise de resultados dos testes intermediários e seus ganhos foram medidos pela relação pré/pósteste.

Enquanto se processaram as diferentes formas de avaliação pode-se constatar melhores desempenhos dos dois grupos que vivenciaram avaliações sistemáticas por Norma ou Critério. Dessa forma, embora o Grupo Controle tenha apresentado, em termos de média, melhor resultado no pré-teste, não conseguiu assegurar a mesma posição nas fases posteriores. Os Grupos Norma e Critério freqüentemente o ultrapassaram e o Grupo Critério demonstrou sempre algum acréscimo quando as análises consideraram o domínio de objetivos, base para avaliação referenciada a critério.

Os ganhos reais nos objetivos corresponderam em média a 6,89 para o Grupo Critério, 5,43 para o Grupo Norma e 4,26 para o Grupo Controle. Para esses grupos os índices de ganho relativo foram, 0,41, 0,55 e 0,54 , para os Grupo Controle, Norma e Critério, respectivamente. Nos ganhos reais, o Grupo Critério distanciou-se 1,46 do Grupo Norma e 2,63 do Grupo Controle, enquanto nos ganhos relativos essas diferenças ficaram em 0,01 para o Grupo Norma e 0,14 para o Grupo Controle. Em termos de medianas, os ganhos do Grupo Critério, nos objetivos, estão distanciados em 2,5 pontos em relação ao Grupo Norma e 4,5 em relação ao Grupo Controle.

A análise inferencial dos dados desse trabalho no tocante ao desempenho em matemática, considerou apenas os acertos nas questões, uma vez que essa é a única base comum aos três Grupos. Constatou-se, assim que houve dentro de cada grupo uma variação nos resultados ao longo do período em que foram testados. Desta forma pode-se dizer que os resultados do pós-teste foram significantemente maiores do que os resultados do pré-teste, indicando que houve 176 
aprendizagem para os diversos grupos que participaram do estudo, independentemente de terem participado de algum tipo específico de avaliação. Os Grupos Controle, Norma e Critério foram estatisticamente iguais no pré-teste, no pós-teste, no teste de retenção e no teste de conhecimento de $2^{\circ}$ grau; o tipo de avaliação não contribui significantemente para que haja aprendizagem, pois todos os grupos apresentaram crescimento estatisticamente significante entre o pré e o pós teste, independente do tipo de avaliação que vivenciaram.

Não se pode prescindir, para a interpretação desses resultados, de levar em conta as peculiaridades da amostra estudada, muito específica em termos da seleção e do direcionamento dado pelo curso profissionalizante escolhido pelos alunos. Trata-se de uma amostra de alunos com aptidões satisfatórias em habilidade numérica, relações espaciais, raciocínio mecânico e rapidez e exatidão. Tais aptidões são importantes para o desempenho no curso de mecânica para o qual a matemática é uma necessidade do dia-a-dia. Esse fato talvez explique a boa aprendizagem realizada, pois todos os alunos dependiam dela para desenvolver outras disciplinas no curso, independente de qualquer condição que viesse a existir. Podemos dizer, então, que a especificidade da amostra talvez tenha contribuído para que não fossem detectadas diferenças significantes entre os Grupos Controle, Norma e Critério, nos resultados do pós-teste, e que pudessem ser relacionadas ao tipo de avaliação.

Entretanto, alguma coisa foi constatada no Grupo critério que possivelmente revela a qualidade da aprendizagem realizada. Tal Grupo manteve-se estável ao nível do desempenho obtido no pós-teste, nas demais situações em que foi testado, enquanto os Grupos Controle e Norma voltaram ao nível do pré-teste. Este fato parece-nos interessante salientar, pois como tivemos o cuidado de controlar as variáveis ligadas ao currículo, como professor, programa, carga horária, material didático, e tipos de provas, uniformizando-os; como as características sócio-econômicas dos diversos grupos apresentaramse muito semelhantes; como não foram significantes as diferenças verificadas em atitude e aptidões, principalmente habilidade numérica; resta-nos hipotetizar como justificativa dessa manutenção de nível, o sistema de comunicação efetivado pela avaliação por critério, capaz de 
propiciar uma aprendizagem abrangente e duradoura, única diferença real que pudemos perceber como aspecto diferenciado para esse grupo.

Com efeito, a implantação desse sistema de avaliação na rede SENAI-SP a partir de 1987 , leva em consideração não somente sua viabilidade no ensino regular, mas, principalmente sua capacidade de detectar problemas, melhorar o processo de recuperação da aprendizagem $\mathrm{e}$ interligar o trabalho de professores e alunos.

Essas consideraçōes partem tanto daqueles que coordenam o projeto no âmbito da rede SENAI-SP e o vivenciam dia-a-dia, quanto daqueles que o supervisionaram e o avaliaram. Algumas falhas são apontadas: há dificuldade para o estabelecimento de critérios que assegurem ao mesmo tempo uma adequação às necessidades do curso e às condições de aprendizagem; há necessidade de melhorar a qualidade técnica dos itens das provas para assegurar adequação ao domínio medido e conferir-Ihes validade de conteúdo; há premente necessidade de agilizar a forma de analise de resultados, sem a qual o processo de avaliação fica comprometido na sua função de comunicador capaz de efetivar ações de melhoria da aprendizagem; há necessidade de modificar o sistema de notação que ainda prioriza a nota em si e não a aprendizagem enquanto realização.

Essas falhas, longe de invalidar o processo de avaliação por critério, dada a sua efetiva contribuição testemunhada por todos aqueles que nele tomam parte, constituem-se em desafios que aos poucos devem ser sanados, seja via capacitação de técnicos e docentes, seja via informatização da parte burocrática do processo, seja via novos caminhos apontados pelas discussões constantes que o próprio processo de avaliação possibilita, suscitando propostas de soluções a serem experimentadas, conduzidas e reorientadas, num dinamismo necessário à evolução de todo o processo.

Quanto às variáveis inteligência e atitude, incluídas nesse estudo, vimos que se apresentaram indiferenciadas para os Grupos Controle, Norma e Critério. As correlaçōes entre essas variáveis e entre elas e os ganhos obtidos, quase nada acrescentariam a essa discussão. No campo da inteligência a par de consideração das peculiaridades da amostra selecionada tendo em vista a necessidade de aptidões ligadas ao raciocínio mecânico e afins, o fato de ocorrerem correlaçōes baixas e na maioria dos casos serem não significantes, leva 
a crer que a matemática como é desenvolvida nos currículos escolares, pouco se relaciona com o raciocínio e o desenvolvimento da inteligência como se faz supor.

Na realidade, a matemática é ensinada na escola regular, com a aparência de acabada, de forma mecânica e formal, visando uma síntese impossível de ser conseguida inteligentemente com a pressa requerida no currículo escolar (Medeiros, 1985).

Não é por outra razão talvez, que os níveis de atitude em relação à matemática verificados nesse trabalho, situam-se em graus tâo baixos, mesmo neste caso, em se tratando de alunos que valorizam a disciplina e dela precisam como ferramenta de trabalho, no campo do desenho técnico ou da mecânica propriamente dita.

De Medeiros , (1985) são os depoimentos a seguir:

"Imersos no discurso matemático sem jamais se afastar dela para contemplá-lo em sua totalidade, professores e alunos agem sem uma clara percepção do significado de suas ações (p.97)... para contornar a falta de um necessário tempo vivido na matemática e não concedido pela escola para que as idéias se estruturassem, havia sempre o recurso de algoritmos variados, que se por um lado levava rapidamente à solução desejada, por outro retirava o sentido da ação realizada (p.98)... eram muitos os casos em que a falta de tempo para uma reflexão mais demorada, somava-se com a estranheza dos significados atribuidos e conduziam a uma total perplexidade que no entretanto não era jamais explorada, mais sempre tida como um sinônimo de confusão mental $e$ incapacidade para a matemática (p.99) ...e assim, de dúvida em dúvida, sempre vendo o professor dar a matéria e reclamar nossa falta de base, íamos construindo um edificio rigoroso de conhecimento exatos onde as demonstrações do ainda não visto, apoiavam-se no já visto e näo aprendido (p.100)... nunca questionando a forma de ensinar que conduzia ao não aprender (p.101)... Por ser a matemática desta forma, uma estranha no mundo do aluno, ...ele recusa esta matemática que lhe é dada como presente, por näo perceber um sentido nessa posse (p.117)."

A autora apresenta um depoimento que dispensa retoques. Parece ser este mesmo o retrato do que ocorre com o desenvolvimento curricular da matemática e outras disciplinas afins. 
Para Machado (1981),

"a matemática tem sido ensinada em todos os níveis com uma ênfase que consideramos exagerada na linguagem matemática. A preocupação central parece ser escrever corretamente, falar corretamente, em detrimento essencialmente do papel que a matemática pode desempenhar quanto ao favorecimento de um pensamento a um tempo ordenado e criativo;... com freqüência muito grande o pensamento situa-se a reboque da linguagem matemática" p. 147.

Os professores e alunos que participaram desse trabalho também têm idéias dos desencontros vividos pelo ensino da matemática. Eles são unânimes em valorizar a matemática, sendo freqüente percebê-la em posição de muito destaque. $O$ fato de ter sido explicitado que as demais disciplinas são uma aplicação prática da matemática e de que ela ensina a pensar, ilustram essa idéia.

Eles que lidam com o problema de desenvolver programas em tempo recorde como corrida de velocidade, são unânimes em opinar pela redução dos mesmos inclusive para atender também à necessidade de torná-lo aplicável. Isso se traduz nas idéias de que a matéria é abstrata e o aluno não vê uma aplicação imediata do que aprende, além de que se usa quase nada da matemática; sua importância maior é a rapidez de cálculo, tomada no caso como rapidez de raciocínio.

D'ambrosio, (1986) é de opinião que

"o ensino da matemática ou de outra qualquer disciplina de nossos currículos escolares, só se justifica dentro de um contexto próprio de objetivos bem delineados dentro do quadro das prioridades nacionais... a prioridade nacional absoluta é a melhoria da qualidade de vida... é absolutamente essencial que ataquemos os problemas de metodologia para trazer esse conhecimento ao nível de sua utilização quase imediata. ... metodologia curricular desgastada... e que de nenhum modo conduz a uma apreciação dos problemas em que a sua contribuição seria tão essencial (p.21)... no $1^{\circ}$ e $2^{\circ}$ graus, o que mais se deveria desenvolver é a sensibilidade para apreciar esses problemas... muito pouco do que se faz em matemática é transformado em algo que possa representar um verdadeiro progresso no sentido de melhorar a qualidade de vida (p.22)... a ênfase estaria em despertar no estudante curiosidade e espírito inquisitivo que aliado a algum 
gosto pelo assunto o motivaria a procura tratamento mais aprofundado e mais rigoroso (p.23)... o quanto de profundidade $e$ de rigor ... jamais poderá ser imposto por um currículo rígido... o que o aluno aprende na escola é de menor importância do que a capacidade que ele adquire para aprender coisas novas quando motivado" ( $p$. 23).

A indicação mais abrangente dada pelos professores pesquisados para efetuar um bom ensino inclui o processo de avaliação, conforme a sugestão de que sejam utilizados recursos múltiplos para explicação da matéria; meios para resolução conjunta e individual de exercícios práticos; formas diversificadas de verificação aula a aula, para detectar falhas e buscar a eliminação de todas as dúvidas. Completam, mostrando a necessidade de solucionar a faita de encadeamento, a falta de compreensão dos conceitos e a falta de tempo, insuficiente, às vezes até para completar o raciocínio.

Para detectar falhas de forma assim freqüente e compreensiva, o sistema de avaliação a ser adotado deve ser capaz de levantar questões, esclarecer dúvidas, mostrar ao aluno sua evolução e permitir uma comunicação passo a passo capaz de torná-lo elemento ativo, integrante das decisões de recuperação e melhoria da aprendizagem. Entre os alunos que vivenciaram a avaliação por critério ficou a sensação da importância de uma verificação abrangente, diversificada, que conceda oportunidades para rastrear um domínio de conhecimento e tempo suficiente para raciocinar e decidir; além disso, ficou a percepção de que a avaliação ajuda a melhorar a aprendizagem, ao final traduzida em notas.

Esses alunos apesar de todo o processo desenvolvido não conseguiram no momento perceber a avaliação em todo o seu raio de ação, abrangendo desde o levantamento de informações, sistematização, discussão e divulgação dessas informações, até ao levantamento de soluções alternativas e adequação das decisões às necessidades de melhoria do trabalho pedagógico.

Para finalizar essa exposição cabe confirmar a importância da avaliação baseada em critério para o acompanhamento do trabalho pedagógico, tendo em vista a melhoria de sua qualidade. Face aos resultados apresentados e considerando tanto as características da amostra quanto o reduzido tempo destinado à prática de tipos 
diferenciados de avaliação, fica a sugestão de que novos estudos sejam realizados com amostras mais diversificadas e para outras disciplinas do currículo em outras séries e graus de ensino regular. Acreditamos que o acompanhamento de uma ou mais turmas durante um tempo mais longo seria necessário para confirmar a sua estabilização num patamar mais elevado de aprendizagem e verificar se amostras menos específicas do que a desse estudo poderiam apresentar resultados diferenciados ao final do processo, por ocasião da aplicação do pósteste.

\section{REFERÊNCIAS BIBLIOGRÁFICAS}

AIKEN JR., Lewis R Attitudes toward mathemactis. Review - of Educational Research, (40) : 551-596, 1970.

. Update on attitudes and other affective variables in learning mathematics. Review of Educational Research , (46): 293-311, 1976.

AIKEN JR. Lewis R. et alii. The effect of attitudes on performance in Mathematics. Journal of Educational Psychology, 52 (1): 19$24,1961$.

ANASTASI, Anne. Testes psicológicos. Trad. Dante Moreira Leite. 2 ed. São Paulo, EPU, 1977.

BECKER, Jerry P. e YOUNG JR., Courtney D. Designing instructional methods in mathematics to accommodate different patterns of attitudes. Journal for Research in Mathematics Education, 9 (1): 4-18, jan. 1978.

BENNET, G. K. et alii. Testes de aptidões específicas - DAT: manual Trad. Eva Nick. Rio de Janeiro, CEPA, 1959. 43p.

BLOOM, B. S. Learning for mastering. Evaluation Comment, 1, 2 1963.

BLOOM, B. S. et alii. Manual de avaliação formativa e somativa do aprendizado escolar. Trad. Lilian Rochlitz Quintão e outros. São paulo, Pioneira, 1983.

BRASSELL, Anne et alii. Ability grouping, mathematics achievement and pupil attitudes toward mathematics. Journal for Research in Mathematics Education, 11 (1): 22-28,jan. 1980. 
BRITO, Maria do Socorro T. Avaliação da Aprendizagem: a prática da avaliaçâo decorrente dos principais modelos de ensino. Educação e Seleção, São Paulo, (9): 17-26, jan/jun. 1984.

Avaliação da Aprendizagem. IN: WITTER, G. P e LOMONACO, J. F. B. org. Psicologia da Aprendizagem: aplicações na escola. São Paulo. E P U , 1987.

Avaliação da Aprendizagem: apresentação de alguns problemas. Educação e Seleção , (17) 53-71. jan/jun 1988.

BRUNER, J. S. The relevance of Education. New York, Norton, 1971.

BUTCHER, H. J. A Inteligência Humana. São Paulo, Perspectiva, 1972.

CASTILHO, Adail Victorino. Análise de novas perspectivas para o estudo da inteligência humana: as medidas de raciocínio analógico e sua inserção no panorama atual da pesquisa. São Paulo, 1985. 180p. Tese (Doutorado). Instituto de Psicologia, Universidade de São Paulo.

CARVER, R. P. , Two dimensions of tests: psichometric and edumetric. American Psychologist, 29 : 512-518. 1974.

CRONBACH, R.J. Test validation. IN: THORNDIKE, R. L. ed. Educational measurement. 2 ed. Washington, American Council on Education, 1971.

D'AMBRÓSIO, Ubiratan. Da realidade à ação: reflexões sobre educação e matemática. São Paulo: Summas, Campinas. Ed. UNICAMP - 1986.

DE CECCO, J. P. The psychology of learning and instruction: educational psychology. New Jersey, Prentice Hall, 1968.

DEPRESBITERIS, Léa et alii. Os passos da avaliação da aprendizagem. In: CENAFOR. Programação Aberta. São Paulo, 1984.

EBEL, Robert L. Essentials of educational measurement. New Jersy Prentice Hall, 1972.

GODMAN, R. I. et alii. The effetiveness index as a comparative measure in media product evaluations. Educational Technology, New Jersey, (9) : 30-34, sct. 1980. 
GONÇALVES, Walter Vicioni. Formação profissional em mecânica de precisão. Trabalho apresentado ao $3^{\circ}$ Seminário para Planejamento Estratégico, Rio de Janeiro, set. 1987.

GREEN, Thomas F. A Topology of the teaching concept. IN: HYMAN, Ronald. Conteporary thought on teaching. New Jersey, Prentice Hall, 1971.p. 71-78.

GRONLUND, N. E. Measurement and evaluation in teaching. New York, Macmillan Publishing, 1976.

.O sistema de notas na avaliação do ensino. São Paulo, Pioneira, 1979.

HALADYNA, Ton et alii. A causal anlysis of attitudes toward mathematics. Journal for Research in Mathematics Education, 14 (1): 19-29, 1983.

HIMEL, Erika. Tendencias actuales en la evaluaction del rendimento escolar. Revista de Tecnologia Educativa, Santiago, 5 (2/3): 171-194, jul. 1979.

HUSEN, T. International study of achievement in mathematics: a comparison of twelve countries. New York, John Wiley, 1967. $2 \mathrm{v}$.

INEP - UFPB Estudo nacional do ensino aprendizagem da matemática. João Pessoa, 1982. mineo.

ISAAC, Stephen \& MTCHAEL, Willian B. Handbook in research and evalution for education and the bahavioral sciences. $2^{\mathrm{a}} \mathrm{ed}$. San Diego, Edits Publishers, 1983.

JAKUBOVIC, José et alii. Proposta curricular para o ensino de matemática - $\mathbf{2}^{\circ}$ grau. São Paulo, Secretaria da Educação/CENP, 1986. 206p. (CENP/329).

$\mathrm{KOCH}$, Maria Celeste M. Quando a matemática ajuda a alfabetizar. Revista do Professor , Porto Alegre, 3 (9) : 24-30, jan/mar. 1987.

LEVIN, Jack. Estatística aplicada às ciências humanas. Trad. Sérgio Francisco Costa. São Paulo, Harper \& Row, 1978.

LIKERT, Denis. A technique for the measurement of attitudes. IN:

SUMMERS, Gene F. ed. Attitude measurement. Chicago, Rand MacNall, 1971. p. 149-158. 
LUCKESI, C. C. Avaliação educacional: pressupostos conceituais. Tecnologia Educacional . Rio de Janeiro, 7 (24): 5-8, out. 1978.

.Equívocos teóricos na prática educacional. Rio de Janeiro, ABT, 1984. (Estudos e Pesquisas, 27).

MACHADO, Nilson José. Matemática e Realidade - uma tentativa de caracterização da relação que transcenda uma visão formal - São Paulo, 1981. Dissertação (Mestrado) Pontifíca Universidade Católica.

MCCLELLAND, D.C. Testing for competence rather than for intelligence. American Psycologist, (28): 1-14, 1973

McNemar, Quinn. Lost our our intelligence. Why? IN: CHASE, Clinton I. \& LUDBOW, H. Glenn. Readings in educational and psycological mesurement. Boston. Honghton Mifflin,1966

MCNEIL, J.D. Curriculum A comprehensive introduction. Boston Little. Brow and Co, 1966

MEDEIROS, Cleide Farias. Educação Matemática - Discurso ideológico que a sustenta . São Paulo, 1985. Dissertação (Mestrado) - Pontifícia Universidade Católica.

MIGUEL, Antonio et alii. Proposta curricular para o ensino de matemática - $1^{\circ}$ grau. $2^{a}$ ed. São Paulo, Secretaria da Educação/CENP, 1986. 12p. (CENP, 306).

MILLMAN, J. Criterion referenced measurement. IN: POPHAN, W. J. ed. Evaluation in education - current applications. Berkeley, McCutchan, 1974. p. 311-397.

NATALÍCIO, L. F. S. A relação entre atitude para com a educação e rendimento escolar em dois grupos de status social. São Paulo, 1967. Tese (Doutorado). Instituto de Psicologia, Universidade de São Paulo.

PECHER, Fritz Cristof $R$. et alii. Proposta de planejamento de ensino e avaliação do rendimento escolar. Educação e Seleção, (15): 15-75 jan/jun 1987.

PINTO, L. C. Análise da situação de ensino-aprendizagem. Fortaleza, UFC, 1981. mimeo.

Metodologia da compreensão existencial. Fortaleza, UFC, 1982, mimeo. 
POPHAM, W. J. The case for criterion-referenced measurements. Educational Researcher, 6-10, dec. 1978.

.Educational evaluation. New Jersey, Prentice Hall, 1975.

PROGRAMA de primeiro grau-ensino regular. Diário Oficial do Munić́pio de São Paulo, São Paulo, 31 dez. 1986. Suplemento, 31 (248): 1-4.

RADATZ, Hendrik. Error analysis in mathematics education. Journal for Research in Mathematics Education, 10 (3): 163-172, may 1979.

RAGAZZI, N. Uma escala de atitude em relação à matemática. São Paulo, 1976. Dissertação (mestrado). Instituto de Psicologia, Universidade de São Paulo.

REBOUL, O. O que é aprender? Coimbra, Almedina, 1980.

SCHOFIELD, Hilary L. Teacher effetcs on cognitive and affetive pupil outcomes in elementary school mathematics. Journal of Education Psycology, 73 (4): 462-471, 1981.

SEILER, Lauren H. \& HOUGH, Richard L. Empirical comparisons of the Thurstone and Liker techniques. IN: SUMMERS, Gene F. ed. Attitude measurement. Chicago, Rand McNall, 1971. p. 159-173.

SELLTIZ, Claire \& COOK, Stuart W. A multiple - indicator approach to attitude measurement.. IN: SUMMERS, Gene F. ed. Attitude measurement. Chicago, Rand McNally, 1971. p. 23-41.

SENAI-SP-DCP. Aprendizagem de Matemática: dificuldades dos alunos na $1^{\text {a }}$ série do $2^{\circ}$ grau. São Paulo, 1985 (b). 23p. Aprendizagem de Matemática: relação entre os resultados do $1^{\circ}$ e $2^{\circ}$ semestres da $1^{a}$ série do $2^{\circ}$ grau, em 1986 . São Paulo, 1987. 16p.

Avaliação de resultados na área de educação geral : HP. Matemática $-\mathbf{1}^{\mathrm{a}}$ série - Relatório. São Paulo, 1984 (b). 28p. .Avaliação do rendimento escolar no SENAI-SP: uma visão crítica do ponto de vista dos docentes de educação geral. São Paulo, 1984 (a). 39p.

- Proposta de planejamento de ensino e avaliação do rendimento escolar. São Paulo, 1985 (a). 83p. 
SENAI-SP-DPEA. Teste-diagnóstico de matemática com alunos da $1^{2}$ série do HP - resultados de 1980 e 1981. São Paulo, 1981 $51 \mathrm{p}$.

SIEGEL, Sidney. Estatística não - paramétrica - Trad. Alfredo Alves de Farias. S.Paulo, Mcgraw - Hill, 1979.

SKEMP, Richard R. The psychology of learning mathematics. New York, Penguin Books, 1979.

THURSTONE, L. L. \& CHAVE, E. J. The scale values. IN: SUMMERS, Gene F. ed. Attitude measurement. Chicago, Rand McNall, 1971, p. 142-148.

TOLEDO, M. C. Atitude Tradicionalista em Educação: validae de uma escala e um estudo de mudança de atitude. São Paulo 1978 Dissertação (Mestrado) - Universidade de São Paulo.

TUKEY, J. W. Exploratory data analyses. Reading, Addison - Wesley 1977.

VAN DER MAREN, J. M. O Ensino e o problema da avaliação pedagógica. IN: BONBOIR, Anna Org. Uma pedagogia para amanhã. Trad. Frederico P. de Barros. São Paulo, Cultrix/Ed. USP, 1977.

VIANNA, H. M. \& GATTI, B. A. Avaliação do rendimento de alunos de escolas de $1^{\circ}$ grau da rede pública: uma aplicação experimental em 10 cidades. Educação e Seleção, São Paulo,(17): 5-52, jan/jun. 1988.

VIANNA, H. M. coord. Avaliação do rendimento escolar de alunos do $3^{\mathrm{a}}$ série do $2^{\circ}$ grau - subsídios para uma discussão preliminar. São Paulo, Fundação Carlos Chagas, 1989 ( c ). mimeo.

VIANNA, H. M. Avaliação do rendimento de alunos do $1^{\circ}$ grau da rede pública: um estudo em 20 cidades. Educação e Seleção , (19): 33-98, jan/jun. 1989 (a).

. Avaliação educacional: algumas idéias precusoras. Educação e Seleção, São Paulo, (6): 61-70, $2^{\circ}$ sem. 1982.

.Avaliação na escola de $1^{\circ}$ grau - problemas metodológicas. São Paulo, Fundação Carlos Chagas, 1989 (b). mimeo. .A perspectiva das medidas referenciadas a critério. Educação e Seleção, 2 São Paulo, (2): 5-14, dez 1980. 
.Testes em Educação. 6 ed. São Paulo, IBRASA, 1987.

WANG, S. L. Planejamento da Educação e eficácia pedagógica. IN: BONBOIR, Anna org. Uma pedagogia para amanhã. Trad. Frederico P. de Barros. São Paulo, Cultrix/Ed. USP, 1977.

WEBB, Norman L. Process conceptual knowledge and mathematical problem-solving ability. Journal for Research in Mathematics Education, 10 (2): 83-93, mar. 1979.

WILSON, J. W. Evaluation of learning in secondary school mathematics. IN: BLOOM et alii. Hand book on formative and summative evaluation of student learning . New York, McGraw - Hill, 1971.

WOLF, Frederic M. \& BLIXT, Sonya L. A cross-sectional crosslagged panel analysis of mathematics achievement and attitudes: implications for the interpretation of the direction of predictive validity. Educational and Psychological Measurement, (40): 829-834, 1981.

YOUNG JR., Courtney D. \& BECKER, Jerry P. The interactive of cognitive aptitudes with sequences of figural and symbolic treatments of mathematical inequalities. Journal for Research in Mathematics Education, 10 (1): 24-36, jan. 1979. 


\section{ANEXOS \\ Sistematização da avaliação da aprendizagem com referência a norma}

As atividades que compõem o processo de avaliação estão intimamente ligadas ao próprio planejamento das atividades de ensino. O processo de avaliação por norma, efetuado pelo professor, deve partir de uma tabela de especificação que contemple os conteúdos selecionados para o ensino e o número de questões correspondentes a cada parte, incluindo o nível cognitivo desejado. A execução da avaliação consiste na aplicação dos instrumentos elaborados de acordo com a tabela de especificação e tendo-se o cuidado de garantir a dificuldade média dos itens para propiciar uma melhor discriminação. A análise dos resultados, com base nos dados do grupo como um todo, oferece condições de aquilatar o sucesso do trabalho a partir de algum critério estabelecido.

Um exemplo de tabela de especificação para teste baseado em norma, referente a conteúdos de Matemática, foi elaborado por ocasião dessa pesquisa e é apresentado a seguir com sua respectiva matriz de resultados.

\begin{tabular}{|c|c|c|c|c|c|}
\hline \multirow[t]{2}{*}{ CONTEUDOS } & \multicolumn{4}{|c|}{ Nivel Cognitivo X Questöes } & \multirow{2}{*}{ CRITÉRIOS } \\
\hline & \begin{tabular}{|c} 
Com- \\
putacto
\end{tabular} & $\begin{array}{c}\text { Com- } \\
\text { preensáo }\end{array}$ & $\begin{array}{c}\text { Aplica- } \\
\text { ẫo }\end{array}$ & Total & \\
\hline Fraçōes & & & & & - Correça dos itens \\
\hline 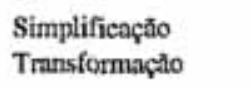 & $\begin{array}{l}2 \\
4\end{array}$ & & & 2 & $\begin{array}{l}\text { I ponto por acerto } \\
\text { - Resultado satisfattónio por aluno }\end{array}$ \\
\hline $\begin{array}{l}\text { Opernçōes } \\
\text { Deetmats }\end{array}$ & 3 & & & $\begin{array}{l}4 \\
3\end{array}$ & posição acima do $I^{\bullet}$ quaurtil \\
\hline Transformą̧äo & 2 & & & 2 & - Resultado satisfatório por item \\
\hline Operafües & 3 & & & 3 & acerto igual ou maior que $70 \%$ das alunos \\
\hline Dfíma perídica & 2 & & & 2 & - Resultado satisfatório para a turma: \\
\hline Intelros relatives & & & & & acerto igual ou superior a $50 \%$ dos itens \\
\hline Operncises & 4 & & & 4 & \\
\hline Teste Eserito 1 & 19 & & & 19 & Obs: Recuperacalo para os resultados ahaixo do $Q_{\text {t }}$ \\
\hline
\end{tabular}

Quadro I - Tabela de especificação pan construção, correção $c$ análise de resultados de teste de matemática. Fonte: Plano de curso de matemática - $1^{2}$ séric Escola SENAI Suiço Brasileira - 1986 
O teste relativo a essa tabela, constou de 19 questões elaboradas de acordo com o nível requerido e conforme as técnicas de elaboração expostas por Vianna (1987). Sua correção e matriz de resultados procuraram atender aos critérios fixados no próprio plano de teste e compōem o quadro a seguir.

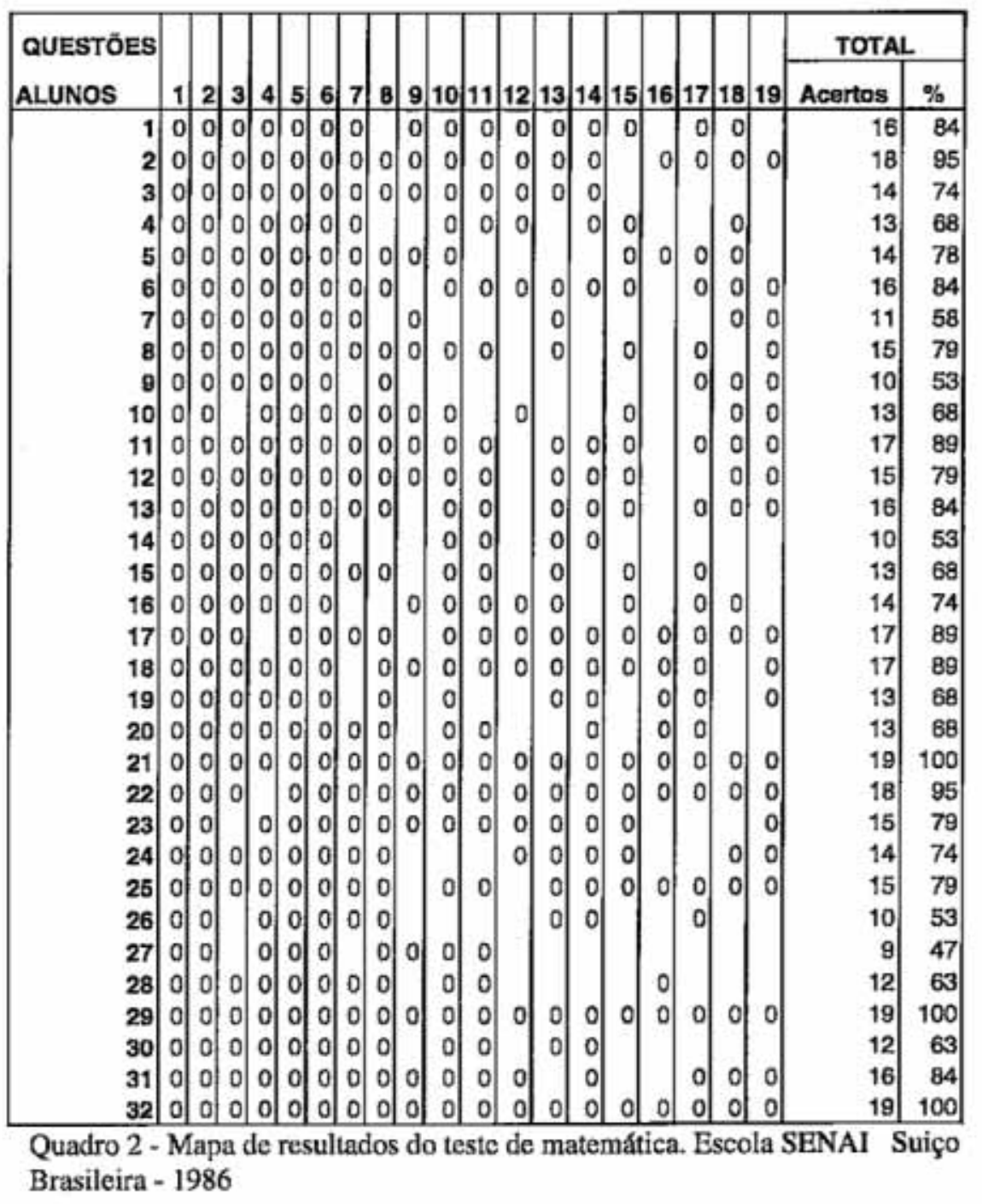

A partir dessa matriz de análise e usando os conceitos de mediana e quartis, mais adequados nesta situação (trata-se de um pequeno conjunto de dados, sem grande variabilidade, como geralmente acontece no dia a dia da sala de aula), do que os conceitos 
de média e desvios, chegamos à seguinte distribuição num gráfico de ramos e folhas.
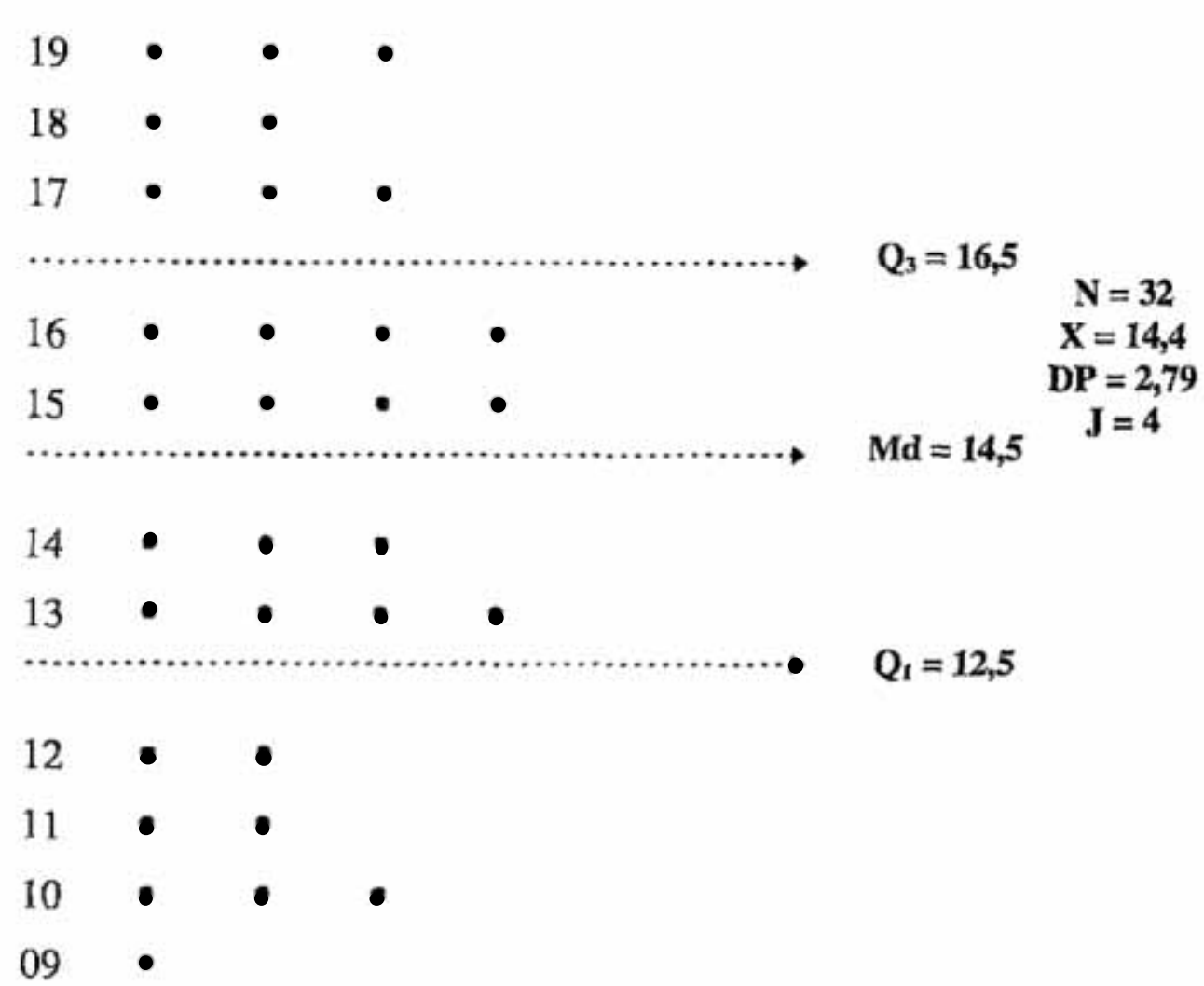

Figura 1 - Gráfico de ramos e folhas - Frequêencia de acertos às questões do teste de matemática. Escola SENAI Suiço Brasileira - 1986

Fonte: Mapa de resultados do teste aplicado

Com esses dados a turma pode ser dividida em quatro níveis:

D - corresponde aos alunos que acertaram entre 9 e12 questões. Pelo critério estabelecido, esse grupo deve participar de recuperação. Ele é composto de oito alunos ( $25 \%$ da turma).

C - Corresponde aos alunos que acertaram entre 13 e 14 questốes. Ele é composto por oito alunos (25\%).

B - corresponde aos alunos que acertaram entre 15 e 16 questöes. Também oito alunos $(25 \%)$.

A - corresponde aos alunos que acertaram entre 17 e 19 questôes, num total de oito alunos $\quad(25 \%)$. 
Esses níveis A, B, C e D seriam as menções correspondentes aos desempenhos de cada aluno no caso de utilização de conceitos. Para notas numéricas na escala de 0 a 100 poderiam servir de notas os pontos percentuais da própria matriz.

Uma outra forma possível de estabelecer parâmetros para a delimitação de conceitos seria a organização de um diagrama de juntas (Fig. 2) a partir dos quartis já calculados (Tukey, 1977).

"O gráfico 'box-plot' ou diagrama de juntas é um componente da análise exploratória de dados (EDA). Tem por base o "Steam and leaf" ou seja, a distribuição dos dados num sistema de ramos e folhas.

$O$ diagrama de juntas utiliza basicamente o $1^{\circ}$ e $3^{\circ}$ quartis. A posição da mediana dá indicações do ponto divisor da metade dos dados da distribuição e oferece elementos para verificar os seus desvios para direita ou esquerda. A distância entre os quartis ou junta é o elemento que determina os limites iniciais dos pontos soltos situados à distância de uma junta dos quartis e os limites dos pontos externos que se localizam à distancia de meia junta dos pontos soltos.

Os pontos soltos e externos por serem considerados atípicos num conjunto de dados, são elementos importantes dessa análise; por isso, torna-se necessário localizá-los a fim de determinar o percentual de dados que abrange. Esse procedimento em se tratando de avaliação de aprendizagem, é bastante útil para orientar a recuperação dos alunos situados nos pontos da escala que se encontram abaixo do $1^{\circ}$ quartil " (SENAI-SP, 1985b p. $12 \mathrm{e} 13$ ).

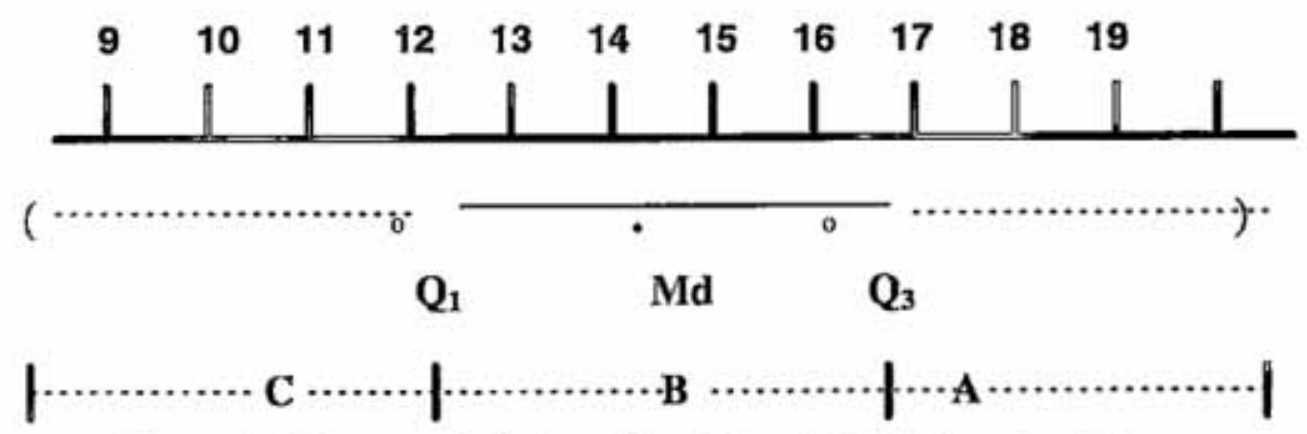

Figura 2 - Diagrama de juntas - Resultados do teste de matemática. 
A partir da junta cujo valor é 4, no caso em pauta, a distribuição pode ser dividida em 3 níveis:

$\mathbf{C} \rightarrow$ corresponde aos alunos que se encontram à distância de até uma junta abaixo do $1^{\circ}$ quartil, teoricamente até o acerto em 8,5 questões. Neste ponto teria início o domínio dos pontos soltos até o limite do valor de menos meia junta, onde começariam os pontos externos indicadores dos elementos realmente diferenciados do grupo como um todo.

B $\rightarrow$ corresponde aos alunos localizados entre o $1^{\circ}$ e o $3^{\circ}$ quartis, totalizando $50 \%$ dos alunos.

A $\rightarrow$ corresponde aos alunos que se encontram acima do terceiro quartil até o limite do valor de uma junta.

O diagrama, quando há dispersão na distribuição dos dados, permite a fixação de até 5 conceitos, sendo considerados dados de reprovação apenas os situados nos pontos externos inferiores.

As informações provenientes dessa análise confrontadas com os critérios estabelecidos a priori no plano da prova dão conta de que:

a) oito das dezenove questões apresentam acertos inferiores ao fixado, de $70 \%$. A questão de resultado mais baixo, é a de $\mathrm{n}^{\circ} 16$ que deve merecer uma revisăo. As demais, com acertos entre 55 e $66 \%$ precisam de um melhor estudo para verificar se houve falha na questão ou na própria aprendizagem.

b) O desempenho da turma como um todo atinge o critério mínimo de $50 \%$, pois num total de 19 questões, apenas 1 aluno ficou com acerto abaixo da metade, teoricamente fixado em 9,5 questões.

c) Os $25 \%$ de alunos abaixo do primeiro quartil, embora não estejam em limites de reprovação, precisam de estudos de recuperação para melhorar a aprendizagem e não para fins de aprovação propriamente dita. Apenas um aluno estaria em situação de reprovação pelo critério nu de $50 \%$ e nenhum deles estaria neste caso, pelos dados do diagrama de juntas. A nosso ver, o diagrama de juntas é um bom auxiliar de decisão quando são analisadas notas provenientes de testes elaborados pelo professor para classes pouco numerosas e para as quais não se pode pensar em máxima variabilidade dos dados. 


\section{Sistematização da avaliação da aprendizagem com referência a critério}

Um exemplo de tabela de especificação para teste baseado em critério, referente ao programa de matemática, foi elaborado por ocasião dessa pesquisa e é apresentado a seguir com sua respectiva matriz de resultados.

\begin{tabular}{|c|c|c|c|c|c|}
\hline \multirow[t]{2}{*}{ OBJETTVOS } & \multirow[t]{2}{*}{ CONTEĆdos } & \multicolumn{3}{|c|}{ NÍVEIS X QUESTÖES } & \multirow[t]{2}{*}{ CRITÍfRIOS } \\
\hline & & Conhecimento & Compreensĩo & Total & \\
\hline $\begin{array}{l}\text { 1 Efetuar cfllculos } \\
\text { com potencias }\end{array}$ & Potencias & 4 & & 4 & $\begin{array}{l}\text { Corregilo dos itens } \\
\text { - notaçlo } 0 \text { pata cada } \\
\text { acerto }\end{array}$ \\
\hline $\begin{array}{l}2 \text { Calcular n miz } \\
\text { quadrada }\end{array}$ & $\begin{array}{l}\text { Processos de } \\
\text { Extraģĭo }\end{array}$ & 2 & & 2 & $\begin{array}{l}\text { Alcance de objetivos } \\
\text { - acerto mator ou igual a } \\
60 \% \text { dos itens com } \\
\text { notaçlo para cada } \\
\text { objetivo atingido }\end{array}$ \\
\hline $\begin{array}{l}3 \text { Simplificar } \\
\text { radicais }\end{array}$ & $\begin{array}{l}\text { Simplificaçato de } \\
\text { radicais }\end{array}$ & - & 3 & 3 & \\
\hline $\begin{array}{l}4 \text { Soma e subtrair } \\
\text { mdicais }\end{array}$ & $\begin{array}{l}\text { Adiçăo e subtrmçẳo - } \\
\text { processo }\end{array}$ & - & 3 & 3 & $\begin{array}{l}\text { Resultado por aluno } \\
\text { - alcance maior ou igual } \\
\text { a } 50 \% \text { dos objetivos }\end{array}$ \\
\hline $\begin{array}{l}5 \text { Multiplicar } \\
\text { radicais }\end{array}$ & $\begin{array}{l}\text { Processo de } \\
\text { Multiplicaçĩo }\end{array}$ & - & 2 & 2 & \\
\hline 6 Dividir melicais & Divisão de radicais & - & 2 & 2 & $\begin{array}{l}\text { Resultado para a furma } \\
\text { - alcance médio maior } \\
\text { ou igual a } 50 \% \text { dos } \\
\text { objetives }\end{array}$ \\
\hline $\begin{array}{l}7 \text { Efetuar } \\
\text { racionalizaçăo de } \\
\text { denominadores }\end{array}$ & Racionalizaçĭlo & - & 4 & 4 & $\begin{array}{l}\text { Resultado para a turma } \\
\text { - acerto maior ou igual a } \\
60 \% \text { da turma }\end{array}$ \\
\hline $\begin{array}{l}\text { TESTE } \\
\text { ESCRITO }\end{array}$ & & 6 & 14 & 20 & $\begin{array}{l}\text { OBS.: Recuperaçäo para } \\
\text { os alunos com } \\
\text { desempenho inferior a } \\
50 \% \text { dos objetivo }\end{array}$ \\
\hline
\end{tabular}

Quadro 3 - Tabela de especificação para construçảo, correção e análise de teste de matemática.

Fonte: Plano de Curso de Matemática - I" série - Escola SENAI Suíço-Brasilcira - 1986 
O teste elaborado para medir o alcance dos objetivos acima consta de 20 questões, sendo 6 no nível de computação e 14 no nível de compreensão. $\mathrm{Na}$ elaboração foram seguidas as recomendações propostas para a construção de instrumentos, considerando que o tipo e a forma das questões para compor um instrumento de medida referenciada a critério pode seguir as instruçōes gerais das técnicas conhecidas e referendadas pela teoria clássica de medidas (Vianna, 1982). Sua correção e matriz de resultados procuraram atender os critérios fixados no próprio plano de teste e compõem o Quadro 4.

O planejamento de ensino, em que se baseia a avaliação, reflete decisões tomadas a partir de análise das necessidades e possibilidades reais dos alunos. Dessa forma, os objetivos imprescindíveis para a orientação e escolha dos conteúdos, estratégias de ensino e atividades de avaliação constituem prioridade para o trabalho pedagogico, considerando os pré-requisitos, o tempo disponível e as demais condições próprias do ambiente escolar. A seleção de objetivos privilegia aqueles mais significativos e abrangentes para nortear a escolha de instrumentos de medida e delimitar os critérios que servirão de base à análise de resultados.

A correção do teste e a correspondente matriz de resultados apresentada no Quadro 4 procuram oferecer condições de análise, conforme os critérios estabelecidos.

Para construir essa matriz de análise, foram usados os conceitos de porcentagem de domínio e os critérios especificados no planejamento e que são compatíveis com a avaliação baseada no padrão absoluto de desempenho. $\mathrm{O}$ primeiro critério foi estabelecido para a correção do teste, marcando-se com 0 cada item corretamente respondido por cada aluno.

$\mathrm{O}$ alcance de cada objetivo foi considerado satisfatório se o aluno acertasse, pelo menos, $60 \%$ dos itens. Cada objetivo atingido pelo aluno foi marcado com a notação 1 .

Com esses dados podem ser efetuados a contagem dos objetivos atingidos para cada aluno e o percentual correspondente ao total dos sete objetivos. A partir disso e conforme o critério de considerar satisfatório para cada aluno, o alcance de $50 \%$ dos objetivos, podemos concluir que 8 alunos, ou seja, $25 \%$ da turma deixaram de atingir o critério. 


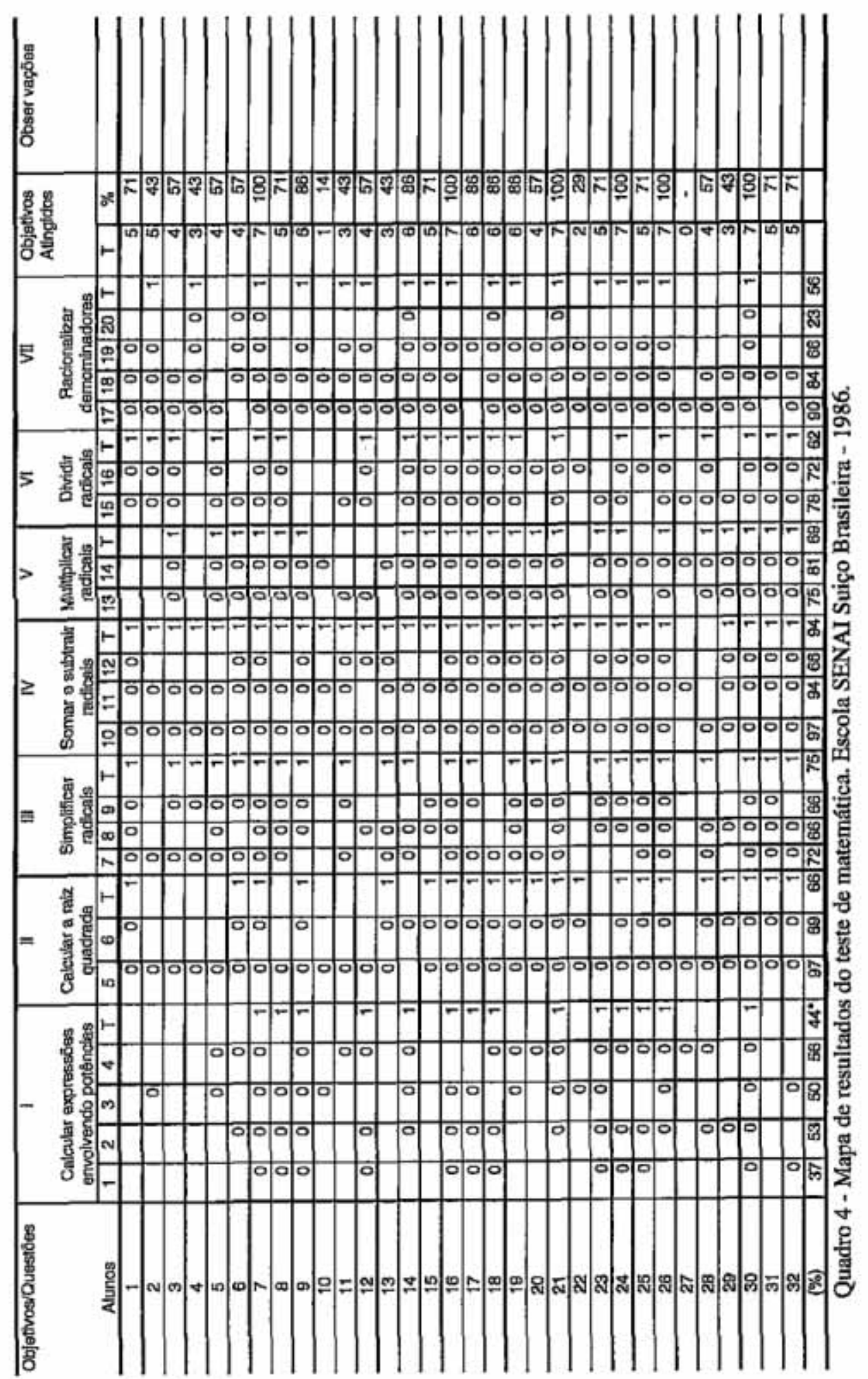


Um não conseguiu atingir nenhum dos objetivos; dois outros atingiram 14 e $29 \%$ dos objetivos; cinco aproximaram-se bastante do critério, atingindo $43 \%$ dos objetivos. $O$ alcance médio da turma atingiu 4,66 correspondente a $66,5 \%$ dentro portanto do critério que foi estabelecido. Admitindo como satisfatório o acerto por questão e o alcance por objetivo a partir de $60 \%$ da turma, observamos que os objetivos "efetuar cálculos com potência" e "racionalizar denominadores" não foram atingidos pela turma. Todas as questões correspondentes ao primeiro desses objetivos também deixaram de atingir o critério. Isso sugere que esse pontos devem ser analisados para verificar se houve falha na aprendizagem ou nas questões apresentadas para a composição de teste. Vale salientar a necessidade de recuperar os oito alunos de rendimento abaixo do critério mínimo; de reformular as questōes que porventura apresentem falhas e tomar decisões de replanejamento se as falhas estiverem relacionadas à dificuldade intrínseca do objetivo ou, ainda, às condiçōes de prérequisitos, tempo e recursos diversos.

Convém salientar que, sem nenhuma estatística especial, essa forma de análise já permitiu um bom número de informações importantes para decisões pedagógicas. Os f́ndices de ganho neste caso não podem ser calculados por se tratar de testagem única. Entretanto, todos os procedimentos estatísticos efetuados anteriormente para a medida baseada em norma, como cálculo de medianas, quartis e juntas, podem ser levados a efeito para tomar decisőes, principalmente as que dizem respeito à retenção de alunos apenas quando situados a partir da distância de uma e meia $(1,5)$ junta abaixo do primeiro quartil.

Com essa complementação de informações teríamos o seguinte:

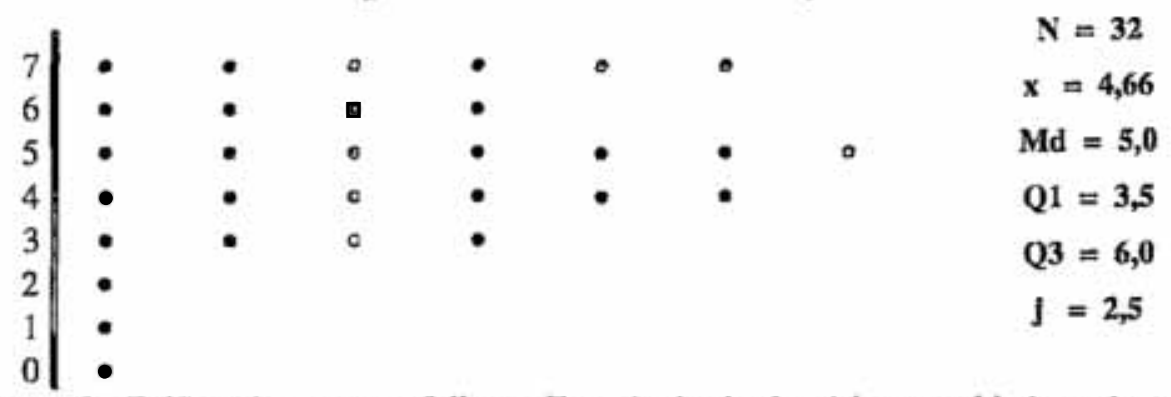

Figura 3: Gráfico de ramos e folhas - Frequiência de domínio nos objetivos do teste de Matemática 


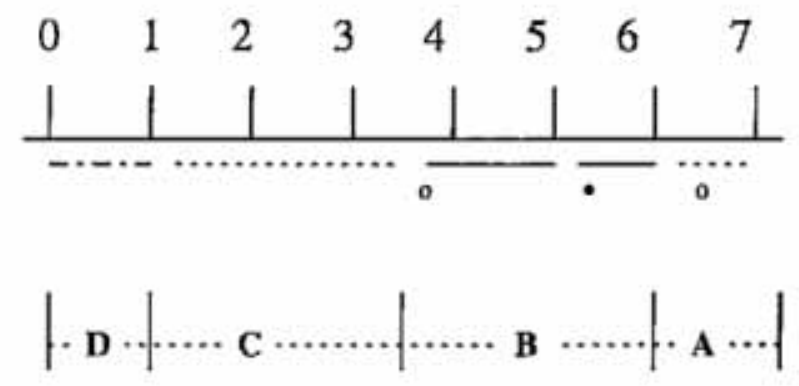

Figura 4: Diagrama de juntas - Resultados do teste de matemática

Em comparação com os resultados do grupo, apenas o aluno de resultado zero discrepa do conjunto, pois o resultado 1 ficou no limite entre o terceiro e quarto níveis, a apenas uma junta de distância do primeiro quartil.

Num contexto de avaliação por critério absoluto o recurso do diagrama de juntas seria aceitável apenas para resolver uma imposição de ordem administrativa, no caso de uma exigência de resultado final por conceitos A, B, C, D e E e não por percentual de objetivos atingidos que seria a notação mais indicada. Outra forma de notação possível seria a dicotômica do tipo atingiu/não atingiu, satisfatório/não satisfatório, neste caso obedecendo ao percentual mínimo adotado como critério, $50 \%$. 